University of Nebraska - Lincoln

DigitalCommons@University of Nebraska - Lincoln

1941

\title{
WILDLIFE OF THE ATLANTIC COAST SALT MARSHES
}

W. L. McAtee

U.S. Fish and Wildlife Service

Follow this and additional works at: https://digitalcommons.unl.edu/usfwspubs

Part of the Aquaculture and Fisheries Commons

McAtee, W. L., "WILDLIFE OF THE ATLANTIC COAST SALT MARSHES" (1941). US Fish \& Wildlife Publications. 255.

https://digitalcommons.unl.edu/usfwspubs/255

This Article is brought to you for free and open access by the US Fish \& Wildlife Service at DigitalCommons@University of Nebraska - Lincoln. It has been accepted for inclusion in US Fish \& Wildlife Publications by an authorized administrator of DigitalCommons@University of Nebraska - Lincoln. 
UNITED STATES DEPARTMENT OF THE INTERIOR FISH AND WILDLIFE SERVICE

\section{WILDLIFE OF THE ATLANTIC COAST SALT MARSHES}

WILDLIFE CIRCULAR 11

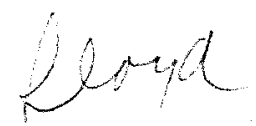


UNITED STATES DEPARTMENT OF THE INTERIOR

Harold L. Ickes, Secretary

FISH AND WILDLIFE SERVICE

Ira N. Gabrielson, Director

Wildlife Circular 11

\title{
WILDLIFE OF THE
}

\section{ATLANTIC COAST SALT MARSHES}

\author{
BY
}

W. L. MCATEE

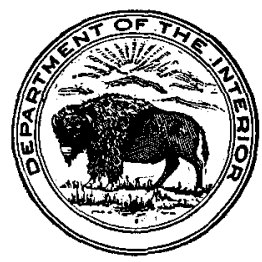

UNITED STATES

GOVERNMENT PRINTING OFFICE

WASHINGTON : 1941

For sale by the Superintendent of Documents, Washington, D. C. - - - - Price 19 cents 


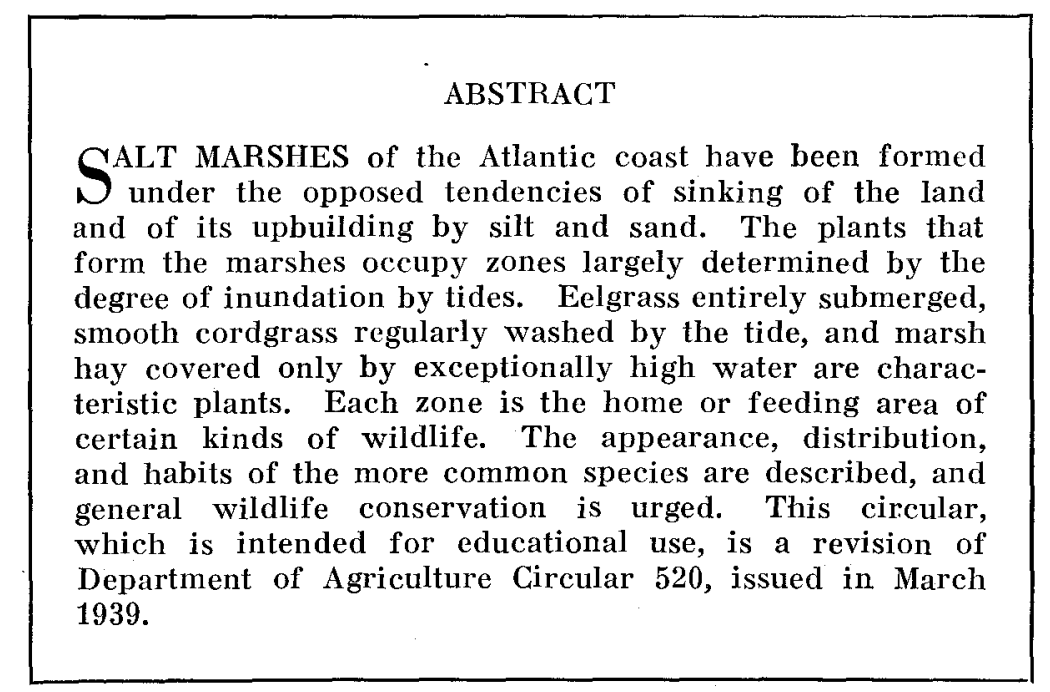

II 


\section{CONTENTS}

Page

The salt marshes and their plant zones

Plants of the zones and their value to wildlife

Seaweeds

Eelgrass. . .

Manateegrass, turtlegrass, and shoalgrass.................... 4

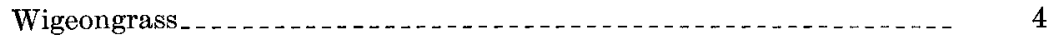

Cordgrass

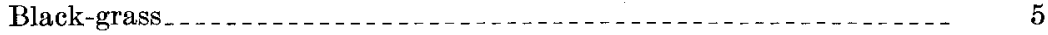

Bulrushes.

- Marsh hay _... 5

Glasswort

Reed..................... 6

Other vegetation

Birds of the salt marshes

More characteristic species

Rails

Sparrows

Ducks_... 9

Bittern $\ldots$

Willet_...............

Marsh hawk

Short-eared owl

Red-winged blackbird 12

Meadowlark

Marsh wren

Less characteristic species

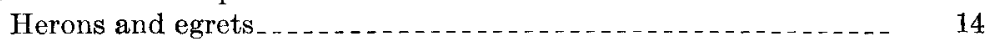

Gulls, terns, and skimmers_...... 16

Waterfowl $\ldots \ldots$

Shorebirds _........... 21

Osprey

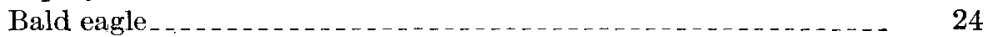

Vultures.

Crows $\ldots$

Kingfisher.

Grackles.............. 27

Cormorants, pelicans, and ibises.

Warblers and swallows ......... 28

Other wildlife of the salt marshes

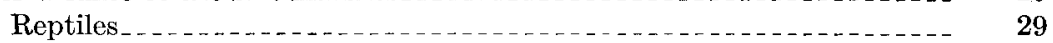

Fishes.

Mammals _... 31 


\section{ILLUSTRATIONS}

1. Smooth, big, and saltmeadow cordgrasses

2. Black duck and blue-winged teal

3. Great blue heron and American egret.

4. Snow and Canada geese..... 15

5. Greater and lesser yellowlegs...... 22

6. Bald eagle and osprey

7. Cottonmouth moceasin, diamondback terrapin, and muskrat_...... $\quad 30$

Figure

1. Clapper rail

2. Willet $\ldots \ldots$

3. Red-winged blackbird

4. Meadowlark . .

5. Herring gull

6. Common tern

7. Black skimmer. 18

8. Pectoral sandpiper

9. Belted kingfisher.

10. Boat-tailed grackle 


\title{
WILDLIFE OF THE ATLANTIC COAST SALT MARSHES
}

\author{
BY W. L. MCATEE
}

Technical Adviser and Research Specialist, Office of the Director, Fish and Wildlife Service

\section{INTRODUCTION}

M ANY salt marshes of the Atlantic coast are now undergoing intensified ditching in furtherance of mosquito control. Possible effects of these operations on wildlife are a matter of great concern to naturalists, who urge that so far as possible the work be carried on in harmony with the highest conservation ideals.

Conservation nieans different things to different people. Some think of protecting only things that can be used, and here again there is more than one school of thought-or at least, of action: One protects only to the date of use and takes what it wishes without planning for replacement-this has been compared to mining; the other strives for replacement, so that there can be sustained use-this has been compared to crop production. There is also protection for beneficial economic tendencies, without direct use-this principle underlying the protection of insectivorous birds. Finally there is conservation for its own sake, the goal of the nature lover.

Whatever his particular interest in wildlife may be, the nature lover is one who, consciously or not, is impressed with the fellowship of all living things, a fellowship that is very real. He sees that in structure, in habits, and in impulses, his wild neighbors often seem much like himself. Either they are very human or he is very much like them; they are indeed blood relatives.

It should never be forgotten that they share with man also the joy of living. No man can possibly get as much pleasure from water as does a porpoise or an otter. However perfect his equipment, man can never be attuned to flying like the terns, the swallows, and other birds whose pliant grace, in calm or storm, is marvelous. No man can be at home in a tree like a woodpecker, which, born, cradled, and housed its whole life in trees, must feel each evening when it comes for rest to its snug retreat that this tree, this nest, is the best and safest place in all the world. 
WILDLIFE' CIRCULAR 11

That wildlife enjoys living in general as much as man, and probably in many ways even more, is a thought that should never be entirely out of mind. Man assumes dominion over wildlife and exercises it as he can, but in so doing he should as far as possible in the case of every creature respect its right to existence, to its chosen home, and to undisturbed enjoyment of its way of life. As has been so often, but not too often, said, in following out ideas for readjusting wildlife and its environment, man should do only what is necessary and no more.

THE SALT MARSHES AND THEIR PLANT ZONES

The Atlantic coast has long been slowly sinking, and its estuaries are being "drowned." It does not take a highly skilled engineer to make convincing observations on these points. Anyone seeing stumps of trees standing well out in salt water, sometimes 10 to 15 feet under low tide, knows that where they are rooted was once dry land and that either the sea has risen or the land subsided, the latter seeming by far the more likely supposition. Such groups of stumps standing in natural position, just as they would in a clearing, may be seen at numerous points along the Atlantic coast. Another evidence of sinking is the channels of streams that extend far seaward under water where they could not have been cut except when the bottom of that quarter was marsh. Engineers have measured the subsidence of the Atlantic coast and obtained results indicating a sinking of about a foot in a hundred years.

This sinking is a great aid to the formation of extensive salt marshes. As the ocean slowly creeps up on the land, salt water kills ordinary land plants. Their place is taken by types that can endure a slight quantity of salt in the soil and live through occasional overflows of brackish water. Such plants occupy the inner, or beach zone, further details concerning which are given later. Just outside of the beach zone, where the soil is a little wetter and there are small channels and sometimes ponds, is the marsh-hay zone. Finally, where salt water stands continuously and there are large channels or guts, lakes, or lagoons, comes the zone of tall cordgrass, or thatch grass. Such are the chief parts and plants of the Atlantic coast salt marshes. The extent of the zones depends on the flow of tide.

The zones of salt-marsh plants are not stationary but rather are ceaselessly shifting. In the relatively quiet waters where the marshes form, sand, washed up by the tide, and silt, caught by such salt-water plants as seaweeds and eelgrass, build up the bottom to the point that cordgrass can grow. This then occupies the soil with its dense and resistant root systems, entraps more mud, and holds the debris result- 
ing from its own annually replaced stems. As this new foundation for plants approaches the mean high-tide level, the marsh-hay types of plants take hold. These build again by catching sand washed in from the sea and loam coming down from the land. Then goldenrod, hightide-bush, and groundselbush may get a start, further firm the soil, and make place for bayberry, chokeberry, wild rose, and other bird-borne plants. An island then is well on its course of development, and if man does not run fire or graze cattle over the area, it may become clothed with trees.

Where the coast is sinking, however, building up must be only a preliminary to tearing down, and as the various zones of the marsh work inland, low islands, even if forested, must give way. When salt water kills their vegetation and the protecting belt of marsh moves landward, the islands are soon worn down by the wash of open water. All this is a slow, a very slow movement, however, and in a lifetime men may see of it only a step or two.

\section{PLANTS OF THE ZONES AND THEIR VALUE TO WILDLIFE}

On the Atlantic coast, seaweeds in variety thrive both in the ocean itself and in saline sounds and lagoons where tidal movement is free. Eelgrass grows in similar waters from Beaufort, N. C., north, manateegrass and turtlegrass subsist on the bottom of bays and creeks of the Florida coast, and shoalgrass is present from the Gulf coast to North Carolina. Wigeongrass grows in usually more quiet and shallow pools and occurs in suitable places along the entire coast. The other plants discussed live in the marshes themselves.

Salt marshes may at first glance seem monotonous, but they have a variety and play of color not lost on the attentive observer. In summer the cordgrass is light green, the marsh hay darker, and the blackgrass very dark green. All but the last fade to russet in fall and to straw in winter. The patches of samphire, or pickle grass, soft green in summer, turn red or even scarlet in autumn.

\section{SEAWEEDS}

The term "seaweeds," popularly applied to almost any underwater plant, is more correctly restricted to the widely distributed marine algae. They have great variety of form and color and include such well-known plants as kelp, bladder wrack, and sea lettuce. They provide cover and pasturage for a multitude of small organisms and contribute also to the food supply of some of the larger creatures. The baldpate, black duck, and greater scaup are known to feed more than casually upon marine algae, and the sea brant, during shortage of its favorite eelgrass, has depended upon them as staple substitutes. 
EELGRASS

Eelgrass (Zostera marina) has narrow, tapelike, dark-green leaves growing from a jointed reddish rootstock and bears its small barrelshaped seeds in thin pods enclosed by the bases of the leaves. It inhabits a considerable range of depths and sometimes is left bare at low tide. In general it thrives best in water in which there is considerable tidal movement. It is a good wild-fowl food plant, and having been the chief dependence of sea brant, its scarcity in recent years, owing to a disease, has had an unfavorable effect on the numbers of that bird. ${ }^{1}$ Eelgrass was eaten to a considerable extent also by the Canada goose, and its seeds by the black duck; it was taken in smaller quantity also by a variety of other waterfowl. The plant is known under a number of local names, as salt-water grass, sea grass, sea wrack, and sea hay. The last two names refer to the windrows of it cast up on the beach, particularly by winter storms. It dries and bleaches there and is used as bedding for domestic animals and for insulation and packing. When plentiful it has been harvested in large quantities for commercial purposes. The fluffy, dry sea hay is recognized as good nest-building material by both birds and mammals.

\section{MANATEEGRASS, TURTLEGRASS, AND SHOALGRASS}

Manateegrass (Cymodocea manatorum), turtlegrass (Thalassia testudinum), and shoalgrass (Halodule wrightii) are less conspicuous plants. Their value as food for wildlife is not scientifically known, but the vernacular names of the first two indicate that they have a popular reputation in that respect.

\section{WIGEONGRASS}

Wigeongrass (Ruppia maritima) has long, threadlike leaves, arising from a whitish, rather zigzag rootstock. The small, black, triangular seeds are borne singly on the tips of short stalks radiating from the end of a more or less lengthy and spiral stem. Wigeongrass grows in varying depths of water, sometimes in a few inches near the shore, sometimes at a depth of 10 feet or more. Though typically an inhabitant of brackish water, it thrives also in water that is nearly fresh and, at the other extreme, in lagoons concentrated by evaporation to a salinity greater than that of the sea. It is also adapted to strongly alkaline waters of the West, in which few other plants will grow. Wigeongrass is a wild-fowl food of the first rank, and all parts of it are eaten.

\footnotetext{
${ }^{1}$ For more complete information see the following: Cottam, Clarence. The present situation regarding eelgrass (Zostera marina). U. S. Bur. Biol. Survey Wildlife Res. and Mgt. Leaflet BS-3, 7 pp. 1935. [Processed.] Obtainable on request from the Fish and Wildlife Service, Washington, D. C.
} 
Smooth, or saltmarsh, cordgrass (Spartina alterniflora) occupies deeper water than any of the other emergent salt-marsh plants and makes up nine-tenths or more of all the vegetation of its zone. It grows in depths ranging from the level of ordinary high tide nearly to that of mean low tide, so that a considerable part of its height is submerged at high tide. Cordgrass is" a true' grass, not a "called" one like those just referred to. It has a rather" stiff, leafy stalk, as much as 10 feet tall, a flowering and fruiting head composed of featherlike parts, and a wiry rootstock. The plant is sometimes used for bedding or mulch. It has local food value for wildlife, the rootstocks being eaten by geese and muskrats; and it makes a good cover for rails and smaller birds, some of which nest in it, especially where bunches of dry eelgrass or other drift have lodged. Plate 1, $A$, illustrates this species; plate $1, B$, a related form ( $S$. cynosuroides).

\section{BLACK-GRASS}

Areas inside the cordgrass zone that are not covered by ordinary high tides but that are subject to flooding by spring and other exceptionally full tides have a variety of vegetation, in which at different points black-grass, bulrushes, cattails, or marsh hay may predominate. Black-grass (Juncus gerardi), so called from its very dark-green color that turns almost black in fall, slender and with a tuft of flowers or seeds at the top, makes large and dense stands but nevertheless permits the growth of numerous other salt-marsh plants within its domain. It is of no known value as a wildlife food plant.

BULRUSHES

Bulrushes of the salt marshes have triangular stems and tufts of flowers or seeds near the top. In the so-called three-squares (Scirpus americanus and $S$. olneyi), without leafy stems, these tufts are lateral, and in the larger leafy-stemmed saltmarsh bulrush ( $S$. robustus) (pl. 1, B) they are terminal. From their fruiting heads can be ground out in the palm large numbers of shiny brown seeds. The seeds, eaten freely by waterfowl, are in some localities an important food supply for them. Bulrushes are a favorite food of muskrats, too, and are used also by them as material for their winter homes.

\section{MARSH HAY}

Marsh hay is a term that covers the slender saltmeadow cordgrass (Spartina patens), saltgrass (Distichlis spicata), and a few other species. A striking characteristic of marsh hay after it has attained height growth is a "lodged" appearance, as if "frozen" in the form $271967^{\circ}-41 \longrightarrow 2$ 
of waves produced by the last strong wind (pl. 1, $C$ ). A variety of other plants may be scattered about in this zone of the salt marsh, and more birds nest here than in the other zones. Flowers that may attract attention are the sea-lavender (Limonium carolinianum), with delicate sprays of tiny lavender blossoms, growing all along the coast; and sea oxeye (Borrichia frutescens), with buttonlike heads, yellow in flower and purplish brown in fruit, growing from Virginia southward. The seeds and rootstocks of some of the plants, including those of saltgrass and small sedges among the marsh hay, are sometimes eaten but are not known to be of much food value, with the exception of arrowgrasses (Triglochin spp.), plants with leaves fleshy at base and a slender stalk bearing three-parted green fruits that are sometimes locally important as food for wild ducks. Salt-marsh hay has at times been important and thriftily harvested but now appears to be little used.

GLASSWORT

A salt-marsh plant sure to attract attention is the glasswort, known also under a variety of names, as saltwort, pickle grass, or samphire (Saticornia spp.). It has flashy, watery-looking, jointed stems and grows in places made so salt by repeated flooding and evaporation that they are bare of other vegetation. This plant is pale green in summer but turns red or even scarlet in fall. Locally its seeds may be important as food for wild ducks, and its fleshy parts are said to be cropped by wild geese.

\section{REED}

Although not characteristic of strongly saline situations, the cosmopolitan common reed (Phragmites communis) grows along the landward side of salt marshes and apparently has increased in recent years. Reed grows 6 to 12 feet or more high, has a strong stem, and bears an ornamental, plumelike, tawny head. The stems are widely used for thatching and for the construction of light fences, lattices, screens, and mats. The plant is of no use to wildlife except for cover.

OTHER VEGETATION

The zone of transition from marsh to upland vegetation contains such growths as rose mallow (Hibiscus moscheutos), with pink flowers 4 to 7 inches across; groundselbush (Baccharis halimifolia) covered in fall with the glistening white parachute hairs of its seeds; switchgrass (Panicum virgatum), the seeds of which are a bird food; saltbush (Atriplex patula); and seaside goldenrod (Solidago sempervirens). The leaves of saltbush, arrowheadlike, and those of the seaside goldenrod, lance-shaped, are somewhat thickened, a characteristic of many salt-tolerating plants. 'The saltbush may be browsed by 
Wildlife Circ. 11, Fish and Wildlife Service
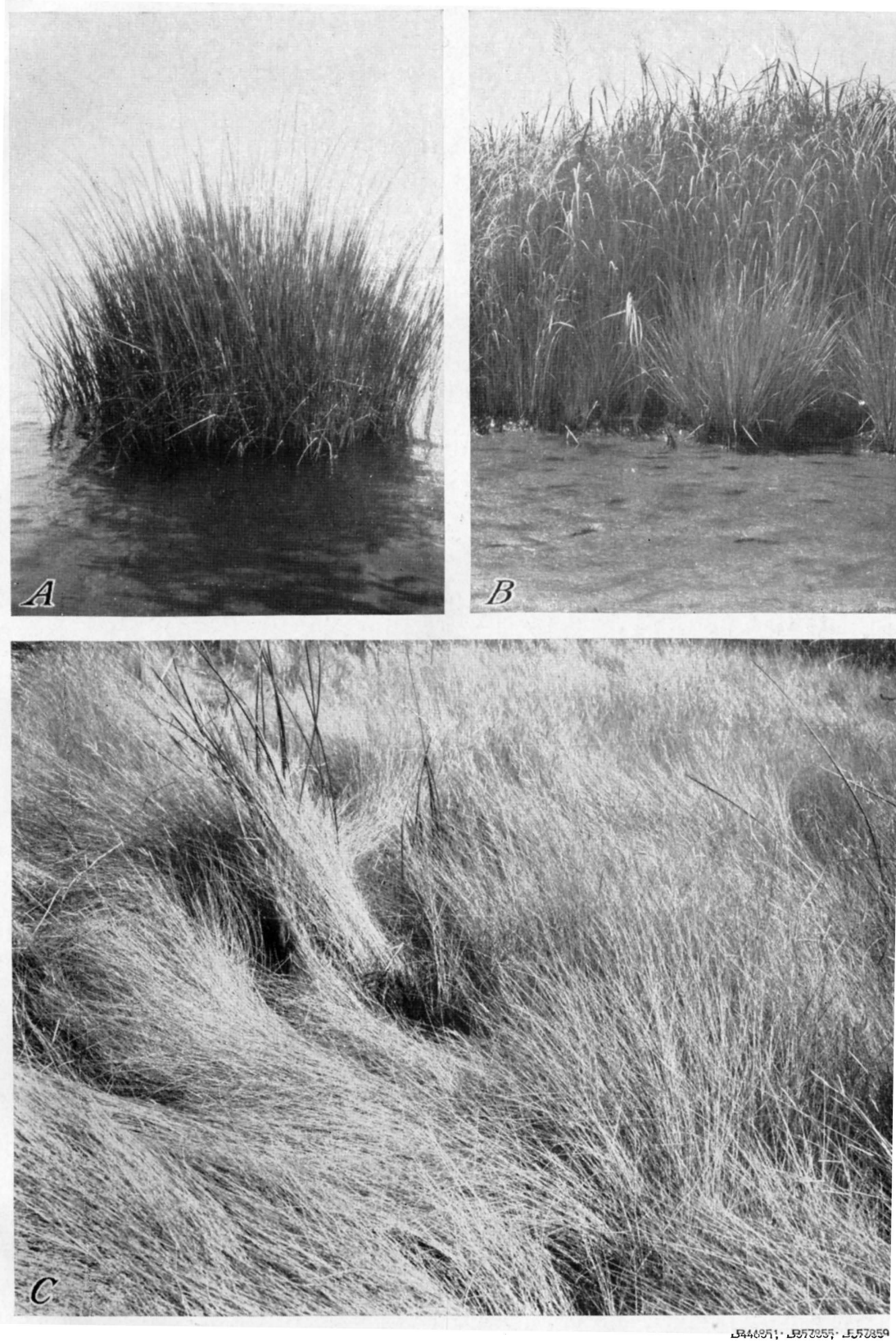

$A$, Smooth, or saltmarsh, cordgrass (Spartina alterniflora); B, big cordgrass (S. cynosuroides), with clump of Scirpus robustus in foreground; and $C$, saltmeadow cordgrass (Spartina patens).

Plate 1

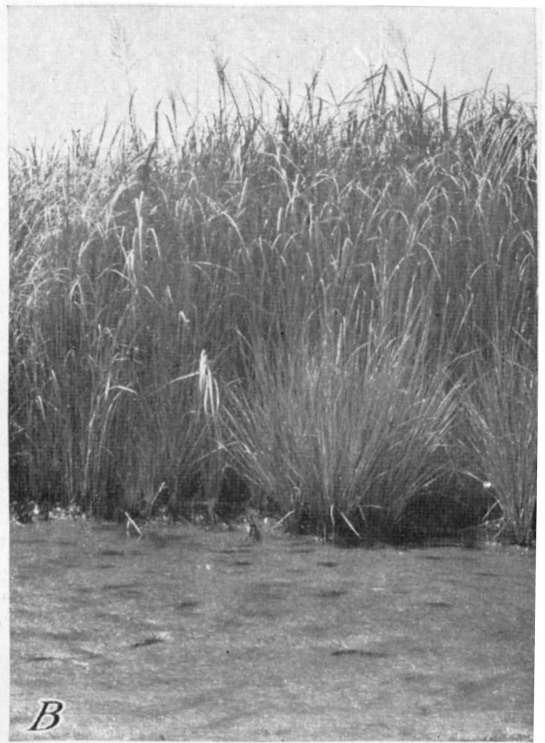



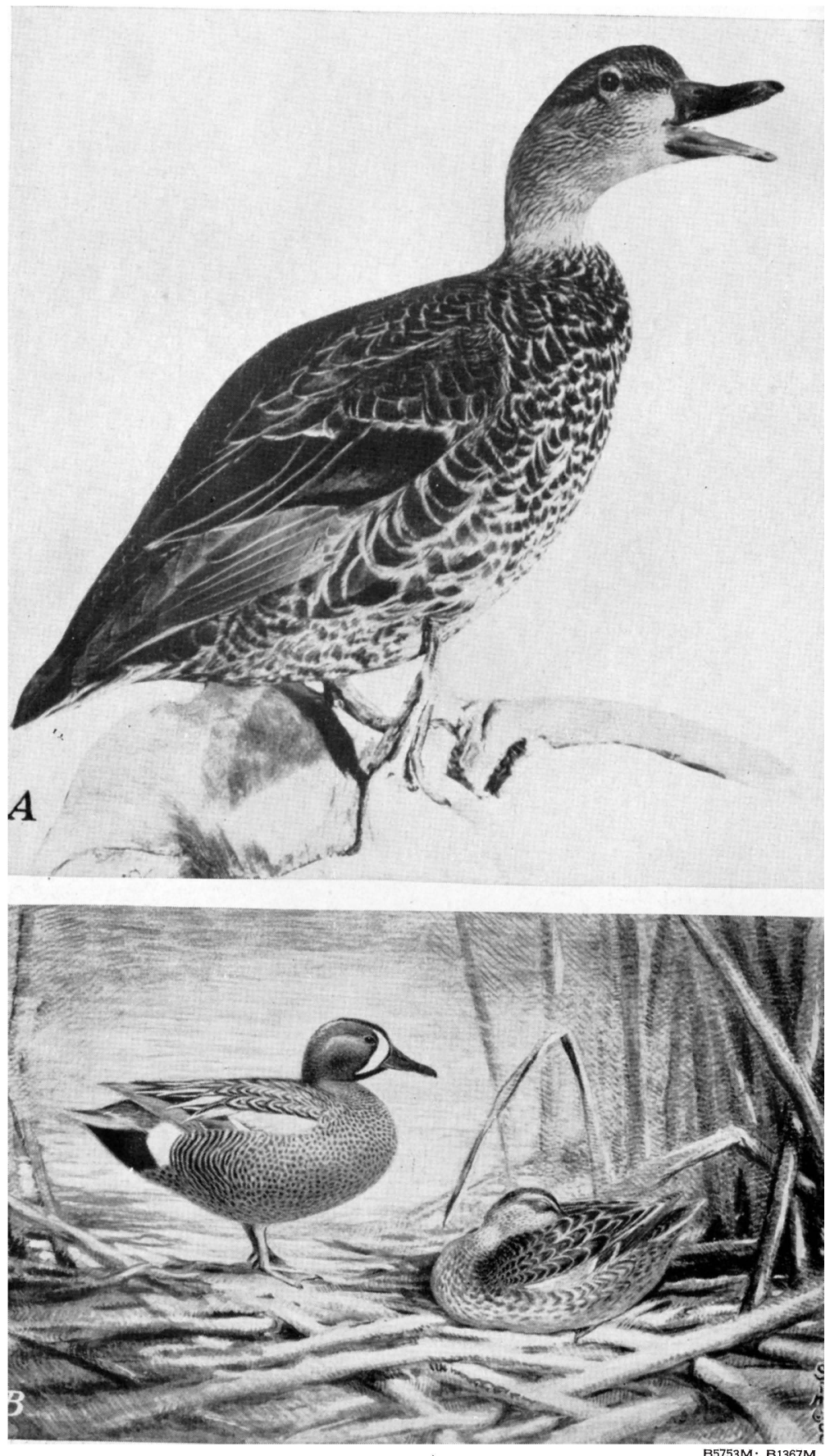

$A$, Black duck; $B$, blue-winged teal. 
geese, or its seeds may be eaten by various birds, but the goldenrod is not known to be so used.

\section{BIRDS OF THE SALT MARSHES}

The discussion of the birds of the salt marshes is divided into two parts, the first relating to the more characteristic species-those that either breed in or closely frequent the usual salt-marsh vegetation-and the second treating the less characteristic species-those that visit the marshes but do not breed in them, except in trees that are not really part of the salt-marsh vegetation. This second section includes also discussion of birds whose true breeding home is in inland wooded swamps or on bare beaches or sandy islands but that may frequently fly over or even descend to feed in salt marshes.

\section{MORE CHARACTERISTIC SPECIES}

Highly characteristic birds of the salt marshes are certain rails and sparrows; other species that breed in them include the black duck, blue-winged teal, bittern, certain shorebirds, and the marsh hawk, short-eared owl, red-winged blackbird, meadowlark, and marsh wren. Birds that nest on beaches and sandy islands are not considered here.

RAIILS

Although rails abound in and are highly characteristic of the salt. marshes, which in the evening may resound with their distinctive calls, a casual observer might spend considerable time in these areas and never see one, for these birds are retiring and elusive and are most active in the morning and evening, when the transient observer is least likely to be in the marshes. By going at those times, however, or by proceeding cautiously and quietly at others, he may occasionally see them. Their nests, usually well concealed, are on or near the ground or supported just over the water. The eggs, pale with dark spottings, often are laid in considerable number, clutches ranging from 5 to 15 . All rails have light and dark barrings on the flanks, and all are narrow-bodied birds that slip about in the dense marsh vegetation so readily that capture by direct pursuit probably is not within the power of their enemies.

The most representative member of the family is the clapper rail (Rallus longirostris) (fig. 1), known also as marsh or meadow hen, which is always in the salt marshes, as it passes even the winter there from New Jersey southward. It is about the size of a onethird grown Leghorn chicken and is largely grayish but has some olive on the back and buffy on the breast. The king rail $(R$, ele- 
gans), although chiefly an inhabitant of fresh-water marshes, occasionally is seen in the salt marshes. It is about the same size as the marsh hen but is darker above and much more reddish brown below. The Virginia rail ( $R$. limicola) may be seen in the salt marshes at

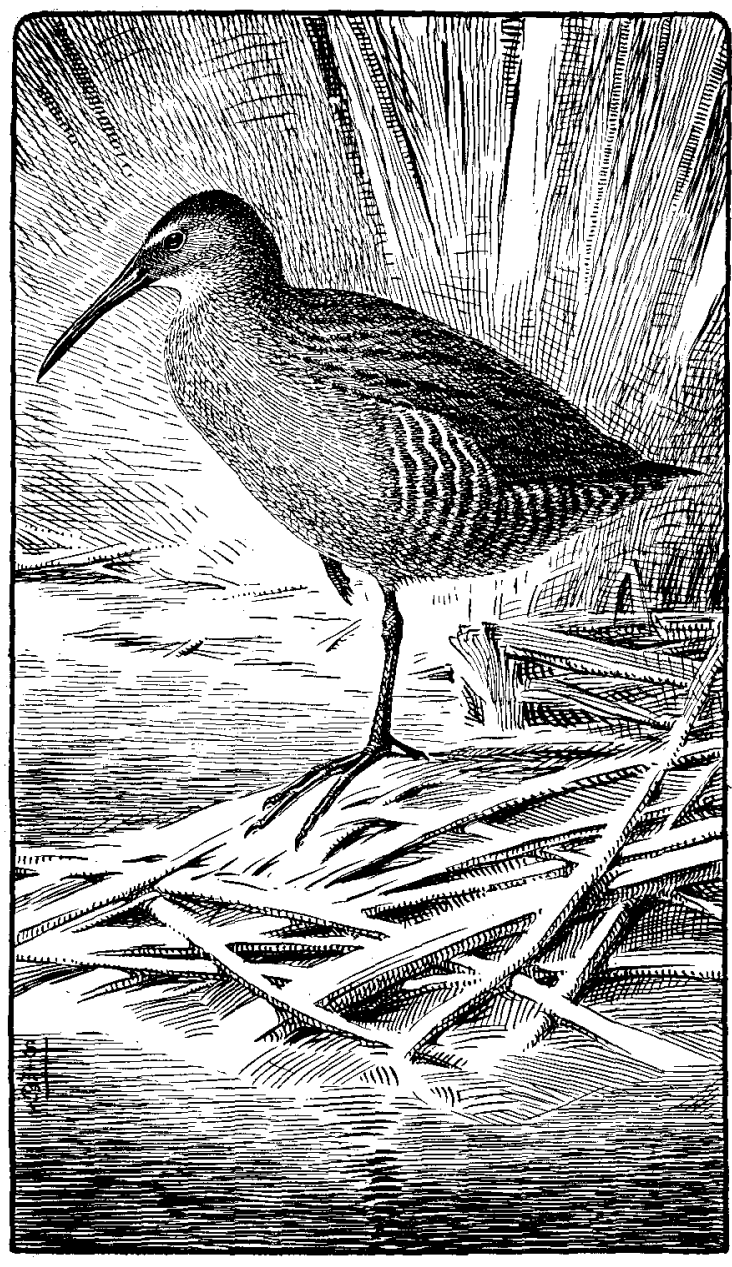

FiguRe 1.-Clapper rail. all seasons but more often in winter. It is half the size of the king rail and of about the same general coloration but has a distinctly reddish patch on each wing. The sora (Porzana carolina), chiefly a freshmarsh species, may sometimes be seen in the salt marshes in migration and winters in them from the Carolinas south. It is a little smaller than the Virginia rail and is mostly olive brown above and blue gray below, with a black marking over the crown, about the base of bill, and on the throat. Two smaller species, the yellow rail (Coturnicops noveboracensis) and the black rail (Creciscus jamaicensis), sufficiently described by their common names, inhabit the marshes, but they are so rare or elusive, or both, that they are not often seen.

The food habits of the rails have not been much studied. The sora habitually fattens in wildrice marshes (fresh) in fall, and the other species, except the clapper rail, frequent these areas to some extent. They all eat insects, snails, and small crustaceans, and it is reported that the clapper rail devours many fiddler crabs. 
Rails are protected by law; but as they are classed as game, an open season is provided for hunting them.

SPARROWS

Birds of another group that are just as characteristic of the salt marshes as the rails, and just as elusive but much smaller, are the sharp-tailed sparrow (Ammospiza caudacuta) and seaside sparrow (A. maritima). They are in the marshes at all seasons, but there is some shifting to the south, at least by the northern colonies. Like many other sparrows these tend to be streaky both above and below, and they have touches of yellow on the sides. They are about as difficult to observe as mice and appear not unlike those small mammals during the brief glimpses that usually are about all that can be obtained of them. When forced to take wing, they flutter only a short distance and drop again into their haven-the marsh. Their songs are unimpressive. Their nests are built in crannies among drift, often of dried eelgrass. About four-fifths of the food of each species is made up of insects, spiders, snails, and sand fleas, and the other fifth of the seeds of grasses and other plants.

Rather close relatives of the true salt-marsh sparrows are the Savannah sparrow (Passerculus sandwichensis) and grasshopper sparrow (Ammodramus savannarum), which have extensive inland breeding ranges but sometimes nest in parts of the salt marshes that are not too wet. They are not easily distinguished by the lay observer.

DUCKs

Black ducks and blue-winged teals breed in the salt marshes, the black duck from North Carolina and the teal from Virginia north. The former may be seen along the entire coast in winter, and the latter from Maryland south. Both species make their nests of a variety of dry plant fragments and line them with their own down, part of which is dragged over the eggs when the sitting bird leaves of its own accord. The white or buffy eggs number from 5 to 15 .

The black duck (Anas rubripes) (pl. 2, A) is a heavy-bodied bird of prevailing dark color, with the lining of the wings white, a character well shown in flight. The female, though smaller than the male, does the talking for the family, having a loud, harsh quack, of which the male's softer note seems a faint echo. Black ducks are usually seen in pairs, and in flight the female leads the way, the male following her every turn and twist. The food is about three-fourths vegetable and one-fourth animal. Pondweeds, including both the eelgrass and wigeongrass of salt and brackish water, are the most important vegetable foods, followed by the seeds 
of grasses, sedges, and smartweeds. About half the animal food consists of small snails and mussels, the common blue mussel being frequently taken. Sand fleas, shrimps, crabs, insects, small fishes, and fish eggs also are eaten.

The blue-winged teal (Querquedula discors) (pl. $2, B$ ) is but little more than a third the bulk of the black duck. The male has a conspicuous white crescent in front of the eye, and both sexes have a large blue patch on the wing that shows well in flight but often appears white unless the light is favorable. The female utters a low quack; the male, a whistling peep. About seven-tenths of the food is vegetable matter, mostly sedges, pondweeds, grasses, and smartweeds, and three-tenths animal, largely snails, insects, and crustaceans. These birds rarely cause damage to man's interests through their feeding habits, and they are important representatives of the wild-fowl group that almost as a whole has been so reduced in numbers in recent years as to demand the most careful protection.

BITTERN

The common, or American, bittern (Botourus lentiginosus) breeds from South Carolina north and winters from Massachusetts south, though uncommonly at the extremes of these seasonal ranges. It seems to be the only one of the heron tribe that breeds in the Atlantic coast salt marshes, an obvious reason being that it regularly nests on the ground, a rude platform of matted vegetation sufficing for a nest, whereas the other herons usually build in trees. The pale-brownish eggs generally number from four to six. The bittern is light brown above and streaked with that color and white below. It has a habit of "freezing" in an erect, sticklike position when surprised. Its strange notes in the mating season have earned it some interesting names, as "dunk-a-doo," "thunder-pump," and "stake-driver." When heard distinctly, the call sounds like plunk$a$-lume but when coming from a distance or when indistinctly perceived, seems more like lunk, lunk, suggesting the "stake-driver" name. The bittern does not depend on fishes for food to so great an extent as commonly supposed but takes considerable numbers of crawfishes and other crustaceans, and even a good many mice.

\section{WITLET}

Of the group of shorebirds that includes the snipes, sandpipers, plovers, and their allies, relatively few nest in the salt marshes; and of these, only one, the willet (Catoptrophorus semipalmatus) (fig. 2), is conspicuous enough to attract much attention. It breeds from New Jersey and winters from South Carolina south- 
ward. It is above average size for a shorebird, being 14 to 16 inches long and having a wingspread of 24 to 29 inches. Though of plain colors, gray above and white below, this bird is recognizable, both on the wing and as it alights with upraised wings, by a broad white band that extends the length of each wing. The nest is a slight hollow lined with grass; the eggs number four (as is usual with shorebirds) and vary in color from white to olive, spotted with brown to purplish. The willet is sometimes noisy, and a common call, an oft-repeated pil-willet, shows that it is one of the birds that have named themselves. The food is reported to consist of insects, mollusks, crustaceans, and small fishes, with a slight admixture of vegetable material.

MARSH HAWK

The marsh hawk (Circus hudsonius) may be seen in all Atlantic coast salt marshes at all seasons. It is easily recognized, being the only member of its group that has the rump white, a character that has given a related European species the name

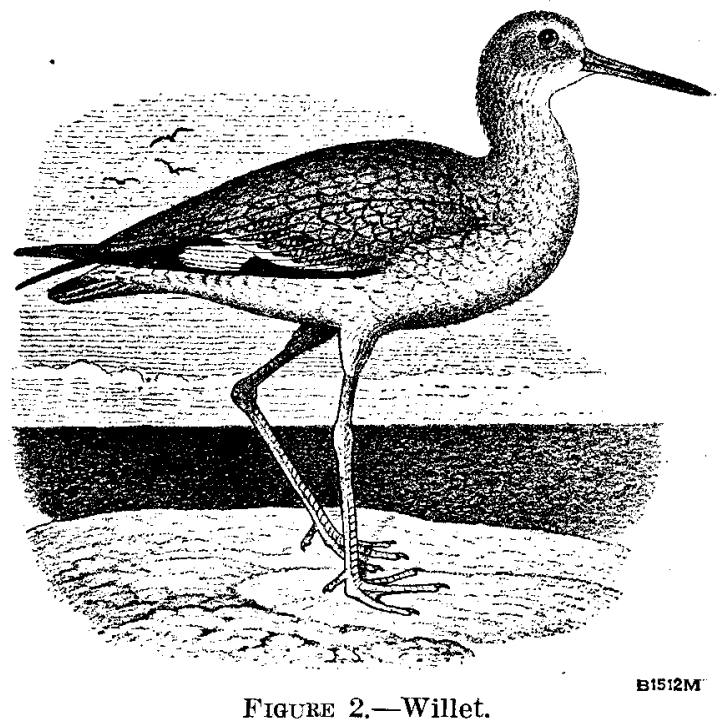
of ring-tailed hawk. The nest may be only a flattened place in marsh vegetation or may sometimes be built up a little with sticks or other material. Usually three to six eggs are laid, bluish or greenish white, sometimes faintly spotted. The marsh hawk appears to fly somewhat lazily, usually not far above the cover it is beating and into which it drops at any chance of catching prey. It feeds. in about equal proportions on mice and birds but captures a variety of other small creatures also and is not averse to partaking of carrion. In some cases, from man's point of view, its numbers may appear to be in need of control.

SHORT-EARED OWL

The short-eared owl (Asio flammeus), named from two short tufts of feathers above the space between the eyes, lives in almost all parts of the world but, as it breeds in open grassy lands, is quite at home 
in salt marshes. It is 12 to 17 inches long but has a wingspread of 38 to 44 inches. The body coloration is tawny, streaked with dark brown, and the large feathers of the wing and tail show considerable patches of tawny. Expert and noiseless in flight, the bird flies more by day than most owls. It preys chiefly on mice and scatters over the marsh pellets of mouse bones encased in fur, remains of meals that are ejected from its mouth.

\section{RED-WINGED BTACKBIRD}

The red-winged blackbird (Agelaius phoeniceus) (fig. 3) may be seen along the entire coast in summer and from Massachusetts south in winter. "It is distinctly migratory, however, and the summer and

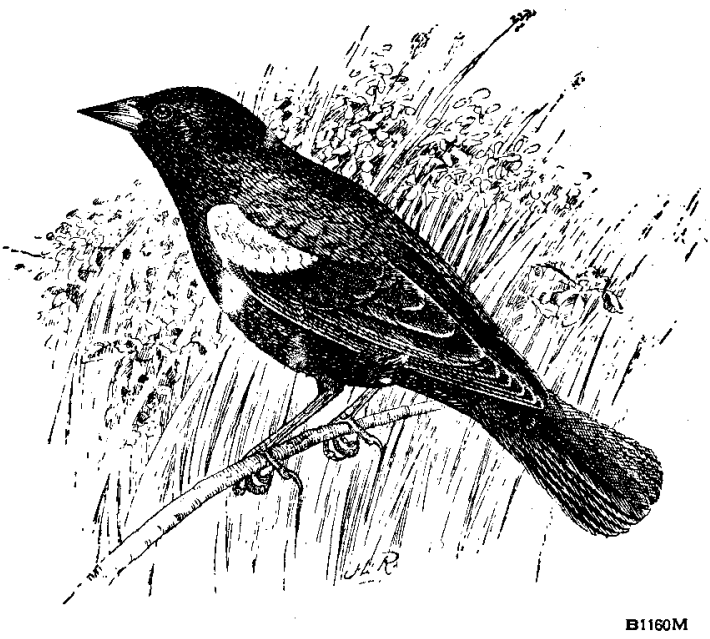

Frgure 3.-Red-winged blackbird. winter populations of a given area no doubt are almost always different groups of individuals. The bird inhabits the whole United States, so perhaps needs no introduction other than calling attention to its bright-red, y ellowbordered epaulets and the gurgling okatee call that the males pour forth at almost regular intervals in spring after they have reached the breeding grounds and "staked out a claim,"

where they await the coming of their mates. The female, brownish black above and more or less buffy and dark streaked below, is smaller than the male. Both sexes often utter a chuck note. The grassy nest is frequently built among the stalks of marsh plants but sometimes in bushes. The eggs, two to five in number, are pale bluish green, spotted and scrawled with brown to purplish. When seattered, redwings probably do more good than harm by their feeding habits, being rather highly insectivorous, but when congregated in great numbers in grainfields after the breeding season, may be disastrous and in need of control.

\section{MEADOWLARK}

The meadowlark (Sturnella magna) (fig. 4), sometimes called marsh quail, may be found in the marsh-hay zone of the salt marshes 
in winter, and it breeds in this zone from North Carolina north. It is a plump bird, brownish above and yellow below, with a black crescent on the breast and white feathers on each side of the tail showing plainly in flight. It builds its nest in grass, usually leaving an arch of vegetation over it so that it is not easy to find. The three to seven eggs are white, irregularly spotted and speckled with brown, purple, or lavender. Formerly the meadowlark was used as a game bird. It is a highly insectivorous species, howevergrasshoppers, beetles, bugs, and caterpillars being its leading animal foods-and deserves protection except when making forays into fields of sprouting corn, peas, and peanuts and into ripening toma-

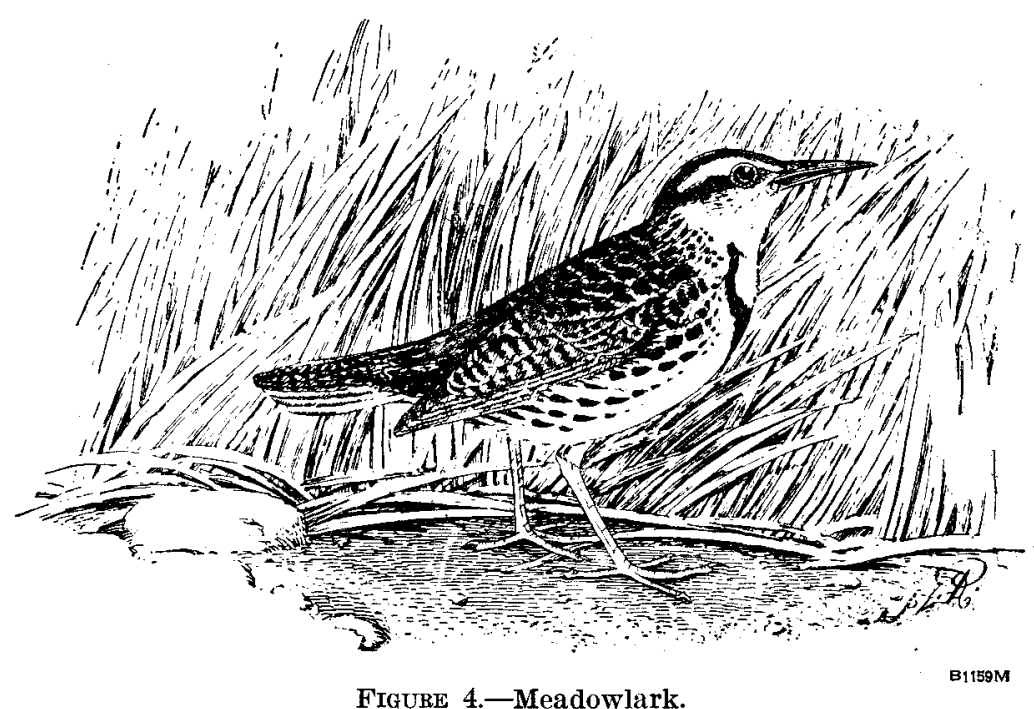

toes in the South during its spring migration. Permits to shoot the birds under such circumstances have been granted, but in general the meadowlark well merits the legal protection it receives.

\section{MARSH WREN}

Various slightly differing forms of the marsh wren (Telmatodytes palustris) breed in suitable places throughout the country and winter sparingly from New Jersey south. Atlantic coast salt marshes are favorite haunts, especially the areas occupied by cattails. Like all wrens these little birds are the embodiment of restless energy, and they sing over and over a hurried series of bubbling, lilting notes. Besides the globular nest woven among and largely composed of cattails and lined with the bird's down, in which the 5 to 10 palebrown to chocolate eggs are laid, this wren builds various extra dummy nests that, unless used as sleeping quarters for the male, 
seem of no use except to keep that tireless fellow busy in their construction. The food seems to be a fair sample of the insects and other small organisms of the highly aquatic environment.

LESS CHARACTERISTIC SPECIES

Most of the common birds of the eastern United States may occasionally be seen in or about salt marshes. The number treated in this relatively brief account must be restricted, however, to the most frequent or conspicuous visitors.

\section{HERONS AND EGRETS}

All the herons frequent salt marshes more or less, and although the bittern, previously described among the more characteristic birds, is the only one to nest there, the great blue, little blue, Louisiana, green, and night herons and the American and snowy egrets may from time to time come to notice. The vocal accomplishments of the bittern have already been mentioned; other herons attract attention by peculiar and usually harsh notes that in a number of cases have suggested local names for the species. When startled, the great blue heron gets under way with raucous croaks and squawks that sound much like "cussing" and therefore is sometimes callec "cranky." The green heron, under similar circumstances, arises with a skeow, which earns it such names as "scouck," "scout," and "cow-cow." The night heron often cries quock and so is termed "quawk," "wop," and "qua-bird."

The great blue heron (Ardea herodias) (pl. 3, A) may occur in the salt marshes at all seasons. It is a grayish-blue bird and stands about $31 / 2$ feet high. When in the air it flaps its large wings slowly with a characteristic undulatory motion. It is an expert spearer of fish but on the whole takes more noncommercial than commercial species, if for no other reason than that the former are more common. ${ }^{2}$ A good many great blue herons are killed under permit about fish hatcheries and rearing ponds, but it would be better, where at all feasible, to screen the ponds. ${ }^{3}$ Shooting herons at the breeding colonies is not only indefensible but also illegal, as the birds are protected by Federal law.

The little blue heron (Florida caerulea) may be seen almost anywhere along the coast late in summer, but in winter and early

\footnotetext{
${ }^{2}$ For further information see the following: Cottam, Clarence, and Uhler, Franfis Marion. Birds in relation to fishes. U. S. Bur. Biol. Survey Wildlife Res. and Mgt. Laflet $\mathrm{BS}-83,16 \mathrm{pp}$. 1937. [Processed.] Obtainable on request from the Fish and Wildlife Service, Washington, D. C.

${ }^{3}$ For suggestions on screening ponds see: McAtee, Waldo Lee, and Piper, Staley Edward. Excluding birds from reservoirs and fishponds. U. S. Dept. Agr. Leaflet 120, 6 pp., illus. 1936. Obtainable from the Superintendent of Documents, Washington, I. C., for 5 cents a copy, stamps not accepted.
} 


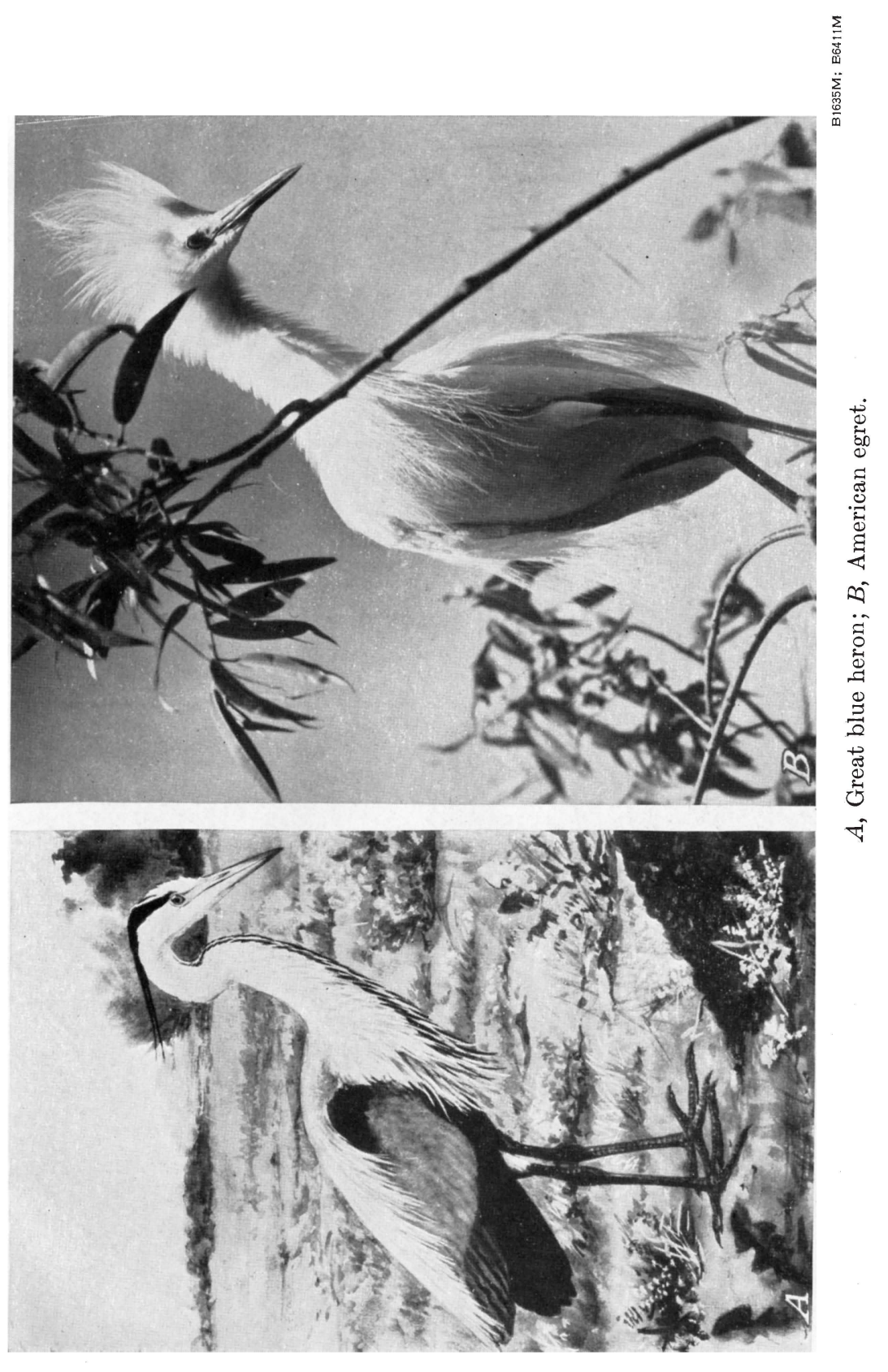



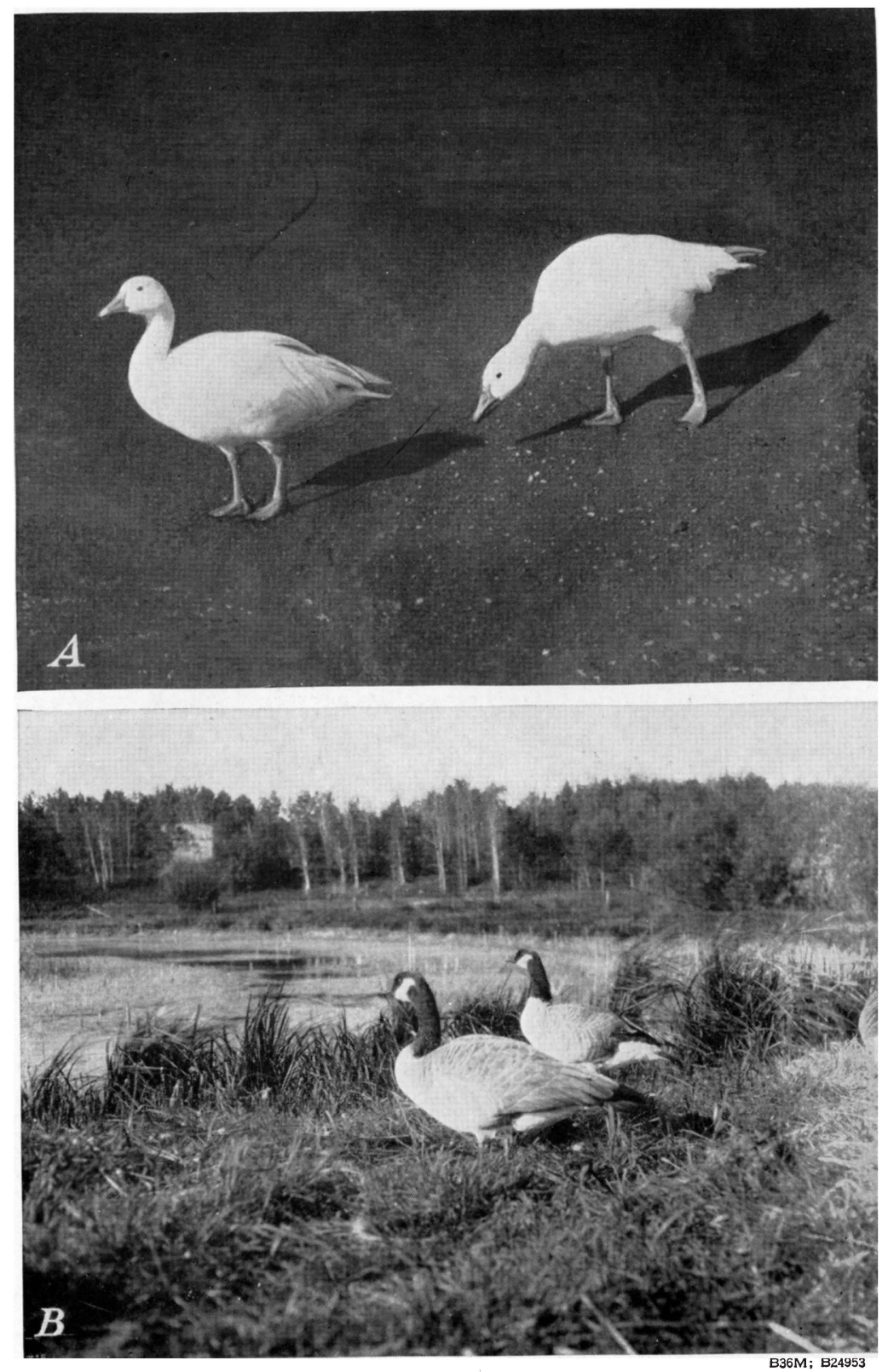

$A$, Snow geese; $B$, Canada geese. 
summer as a rule only from North Carolina southward. It is about half the size of the great blue heron and is chiefly dark slate blue in the adult stage. The young are often white, but intermediate, spotted forms also occur. In the white phase, the dark bill and the smaller size of the bird distinguish it from the large egret and the greenish legs and dark feet from the small egret.

The Louisiana heron (Hydranassa tricolor), about the same size as the little blue heron, may be seen at all seasons from the Carolinas south. Standing, it appears more slender than other herons; on the wing, it is distinguished by the dark head and neck contrasting with the white body.

The green heron (Butorides virescens), the smallest of the tribe here described, is about the bulk of a crow and appears dark, although it is greenish above and reddish below. It frequents bodies of water in woodlands but may occasionally visit salt marshes. It winters from South Carolina southward.

The black-crowned night heron (Nycticorax nycticorax) may be seen in summer anywhere along the coast and in winter from Virginia (casually from Massachusetts) south. Its bill is proportionately thicker at the base than are those of other herons; the top of its head is black, and its general body color is bluish gray. The young in their first winter are grayish brown, spotted and streaked with white and rusty. Night herons nest in colonies in trees, often near the coast. In the nesting season they may visit salt marshes in search of food and at other seasons may adopt them as hunting grounds for protracted periods. These birds are seen mostly in evenings and early mornings but, true to their name, are active throughout the night.

The egrets are white, the large or American egret (Casmerodius albus) (pl. $3, B$ ) having a yellow bill and the small or snowy egret (Egretta thuta) yellow feet, points that must be seen to insure positive identification. The former bird is about two-thirds and the latter about one-third the size of the great blue heron. The large egret breeds from New Jersey south; wanders extensively in summer and early fall, going north even into Canada; and retires in winter to the Gulf coast and southward. The small egret formerly bred as far north as New Jersey but now from North Carolina south. In summer it wanders to the same extent as the large species. and for winter quarters returns to its southern breeding range.

The egrets formerly were especially persecuted for their plumes, or aigrettes. The practice has not yet been entirely stopped, but it has been suppressed to such an extent that the birds have increased from numbers that were approaching the disappearing point to relative abundance, the large species recovering more rapidly than the 
small. In the first stages of the recovery process, the birds resumed their northern wanderings in steadily increasing numbers and to more and more distant points, and later they reestablished breeding colonies at points farther and farther north, where they had formerly bred. The contraction of their populations to the south as their numbers decreased is an interesting phenomenon, as the northern colonies were the least molested, the war of the plume traders upon the birds having been most intensive in the South.

\section{GULIS, TERNS, AND SKTMMERS}

Gulls and terns breed chiefly on islands and beaches, but they are free-flying fowl and from time to time several kinds may be seen

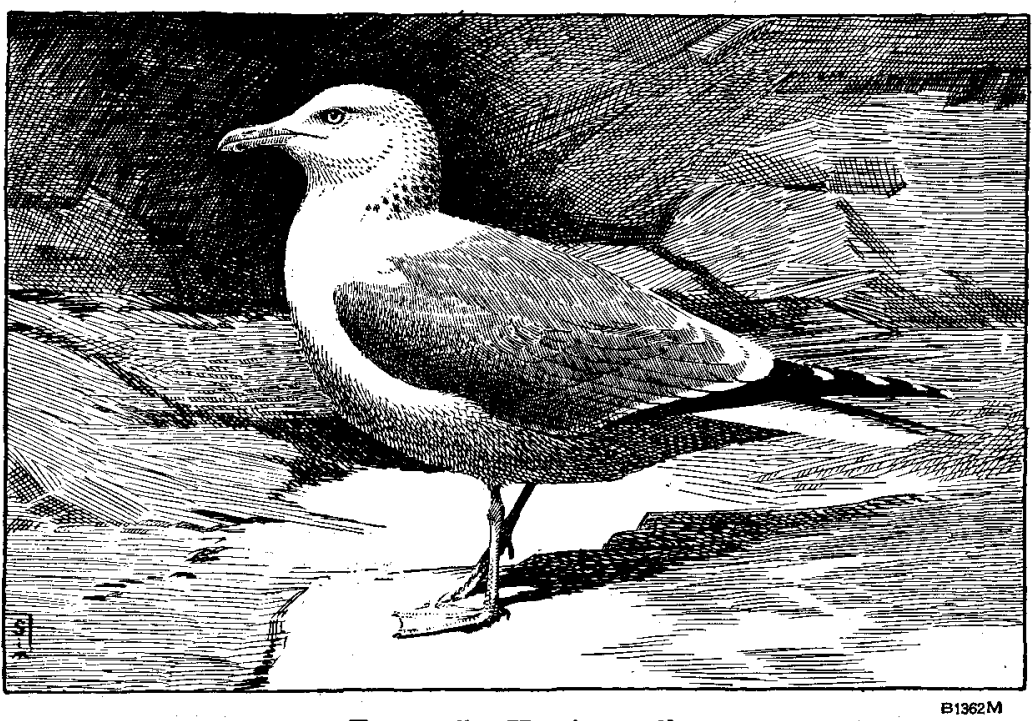

FIGURE 5.-Herring gull.

in the salt marshes. Some are rare or difficult to distinguish and are best omitted from an account like the present. All those here mentioned are protected by Federal law.

The most common gull on the Atlantic coast from fall to spring is the herring, or harbor, gull, the common sea gull (Larus argentatus) (fig. 5). It is somewhat larger than a crow. The back and most of the wing are pearl gray; the head, under side, and tail, white; and the tip of the wing, barred black and white. The species breeds from Massachusetts north and west and winters along the whole coast, from which in fact it is entirely absent only a few weeks in summer.

A similar-appearing but somewhat smaller species, the ring-billed gull (L. delawarensis), present during about the same season, can be 
surely identified in the field only by a black cross bar near the tip of the bill.

The laughing gull (L. atricilla) and Bonaparte's gull (L. philadelphia) are common representatives of another group-the blackheaded gulls. The former breeds commonly along the whole coast and winters from the Carolinas south; the later breeds in the northern interior of the continent and winters along the coast from Massachusetts south. Adults in breeding plumage, which is not attained in full until the second spring after the year in which the birds are hatched, are easily recognized; but in winter the black on the head mostly disappears. The laughing gull is a little the larger of the two species and has a stouter bill. Its back and wings are leaden gray; those of Bonaparte's gull, pearl gray.

Gulls feed on almost anything available and hence figure largely as scavengers. They eat insects, however, as well as mollusks, crustaceans, and fishes, but as they rarely dive are not well adapted to catch-

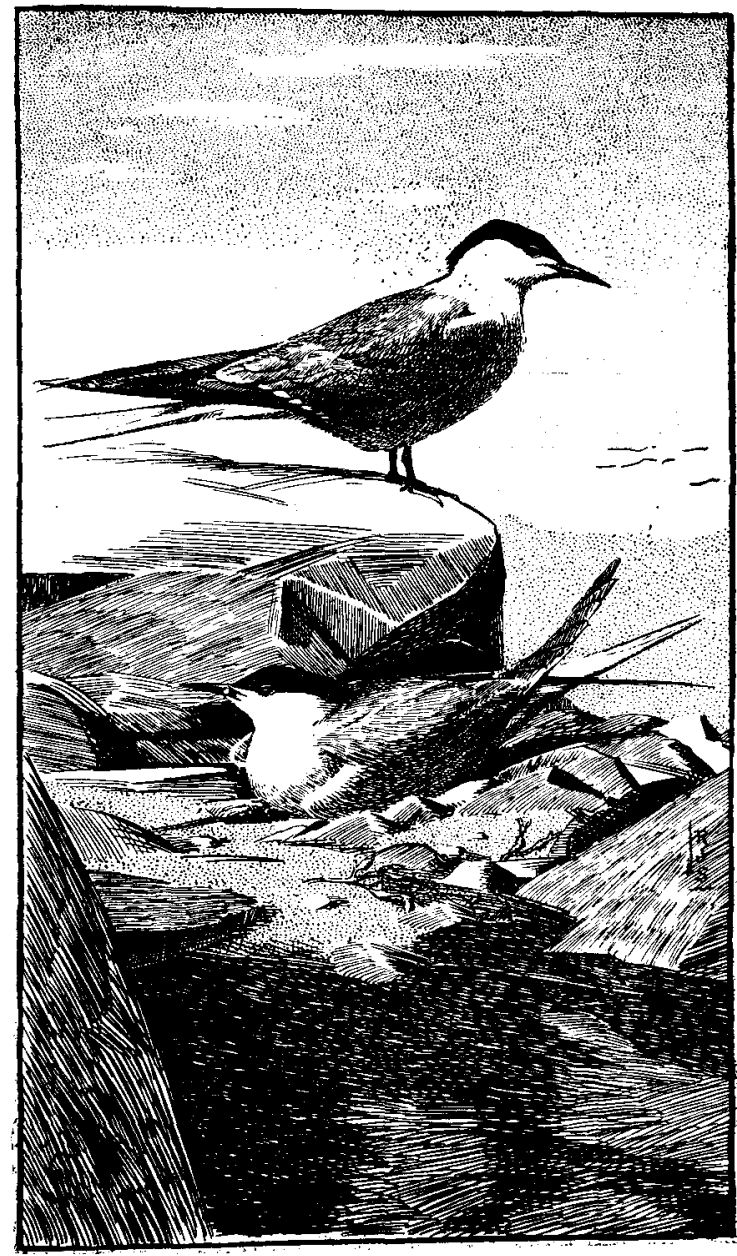
ing live fishes. On the Maine coast, where

Figure 6.-Common tern.

B1683M herring gulls have increased so much as to become objectionably destructive to eggs of other birds and to fishes, clams, and blueberries, steps have been taken to control their numbers.

Expert as gulls are in flight, they are surpassed in this respect by terns, which because of this skill are commonly called sea swallows. 
Terns are mostly pearl gray in color. In adult plumage they have the top of the head black and even in immature plumage have a broad, dark line from the eye around the nape. The crown feathers are elongated so as to form a slight crest posteriorly, and the tail is more or less deeply forked. The bills of terns are more slender and

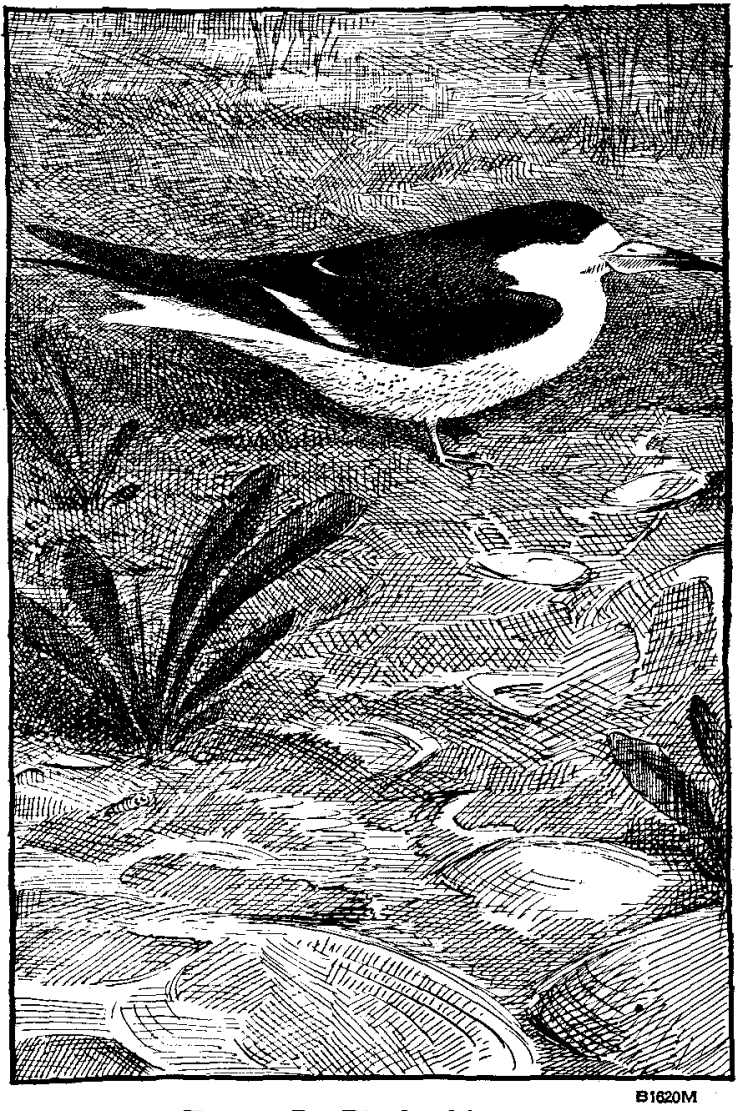

FTaure 7.-Black skimmer. pointed than are the stout beaks with downcurved tips of the common gulls and are pointed more directly downward when the birds are on the wing. The least tern (Sterna antillarum), less than 10 inches long, the only tern that in summer has a bar of white on the forehead in front of the black cap, breeds on islands and beaches from Massachusetts south and winters from the Gulf coast southward.

The common tern (S. hirundo) (fig. 6) and Forster's tern $(S$. forsteri), both from 14 to 16 inches in length and too nearly alike for easy field identification, occur along the coast in $\mathrm{mi}$ -

gration. The former breeds in New England, and both species winter from the South Atlantic coast southward.

The Caspian tern (Hydroprogne caspia) and the royal tern (Thalasseus maximus) are another pair similar in appearance. They are larger birds, about the size of crows, with reddish-orange bills, the former having the tail about twice as deeply forked as the latter. Both may be seen on the South Atlantic coast in winter, and both breed north to Virginia. The Caspian tern occurs farther north also in migration to and from breeding grounds in the northern interior.

The black tern (Chlidonias nigra), easily recognizable by its generally sooty color, breeds chiefly inland and is rather rare in spring 
on the Atlantic coast. It may be more numerous in late summer but is then in very different dress.

Terns seldom exhibit the carrion-eating propensities of gulls but capture their prey alive, either on the wing or, if in water, by plunging. A variety of insects are snatched in air, and small fishes, shrimps, and aquatic insects are taken by partial diving. The black tern is more pronouncedly insectivorous than the other species.

The black skimmer (Rynohops nigra) (fig. 7), a peculiar and striking bird, related to terns and as large as any American species, may sometimes be seen about salt marshes. It breeds on beaches and bare islands as far north as New Jersey and winters from Florida (occasionally South Carolina) southward. It is dusky brown above, with the forehead, lower parts, and the hind border of the wing feathers as seen in flight, white. The bill, its most peculiar feature, is much longer than the head, flattened from side to side like a knife, with the lower part projecting considerably beyond the upper. The bird often flies close to the surface, with the narrowed bill plowing through the water, a habit that has suggested the names "cutwater" and "shearwater." The food is small fishes, so far as known of kinds not used by man. Skimmers are wonderfully good fliers, and flocks carry on elaborate maneuvers in swift unison. One is tempted to call the flocks "packs," as a common call of the birds sounds like the yelping of dogs.

WATERFOWL

In addition to the breeding ducks of the salt marshes already discussed-the black duck and the blue-winged teal-a large number of species may be seen there in migration, though in this circular it is hardly practicable to detail their recognition marks. Ducks can be recognized as such even by those with the least ornithological experience. They are the precious survivors of a very important group of American birds now so greatly reduced in numbers that some of the species are in danger of being exterminated and all need earnest and sympathetic attention.

The mergansers, or fish ducks, not being hunted, have held their numbers better than other ducks. The red-breasted merganser ( $M$ erguts serrator) is the species most likely to be seen in salt water. In winter it may occur anywhere along the coast, but in the East it does not breed south of Massachusetts. Its narrow, saw-toothed bill and its crested head are characteristics common to other mergansers. The male has a greenish-black head and back, white neck and wings, a reddish-brown and spotted upper breast, and finely barred black-andwhite sides. The female and young are much plainer, with the head and neck cinnamon and the back grayish brown. 
and the third, intermediate in size and length of bill, the Hudsonian curlew ( $P$. hudsonicus), has benefited by the protection afforded by the Migratory Bird Treaty Act of 1918 and during migration may be seen in considerable numbers on the Middle Atlantic coast from New Jersey to the Eastern Shore of Virginia. This bird is variegated with brown and white, darker above, paler below, and is 15 to 18 inches long. It is another great traveler, breeding in Arctic North America and wintering south to southern Chile.

Among more familiar shorebirds to be seen in and about salt marshes are the greater and lesser yellowlegs, dowitcher, pectoral sandpiper, and least sandpiper.

Neither species of yellowlegs (pl. 5) breeds on the Atlantic coast, but both may be seen there in migration. The greater yellowlegs (Totanus melanoleucus) winters from South Carolina south and the lesser yellowlegs ( $T$. flavipes) entirely south of the United States. The two species are colored alike: the body is dusky above, speckled with paler, and is whitish below, more or less streaked or marbled with dusky; and in being true to their name, the long legs are bright yellow. The greater yellowlegs is 12 to 15 inches long; the lesser yellowlegs, 9 to 11. The bill of each is one and one-third times as long as the head, a moderate length in proportion to the size of the bird compared with that of the beaks of various other shorebirds. Both species are easily alarmed and take to wing uttering repeated loud, ringing, whistling cries, a habit that in old hunting days gave them the name "tattlers."

The dowitcher (Limnodromus griseus), occurring only as a migrant in the Atlantic coast salt marshes, is a plump-bodied bird, with the bill more than twice as long as the head. The under side of the body is in spring largely cinnamon and in winter gray, the rump is chiefly white, and the tail is barred black and white. Dowitchers are far less excitable than the yellowlegs and may sometimes be closely approached. They remain by preference in compact flocks and probe the mud industriously with their long bills.

The pectoral sandpiper (Pisobia melanotos) (fig. 8), or grassbird, a particular habitue of areas of short grass soppy with water, is seen on the Atlantic coast only in migration. It is 8 to $91 / 2$ inches in length, with the bill a little longer than the head. The top of the head is streaked brownish black and light chestnut, the back feathers are brownish black edged with paler, the upper breast is pale brownish streaked with dusky, the belly and rump are white, and the middle tail feathers are darker than the others. A note, kriek, kriek, given by the bird when flushed, has suggested one of its local names, "creaker."

There are several small sandpipers of very similar appearance, but it is impracticable to differentiate them here, though a common 
Wildlife Circ. 11, Fish and Wildlife Service

Plate 5
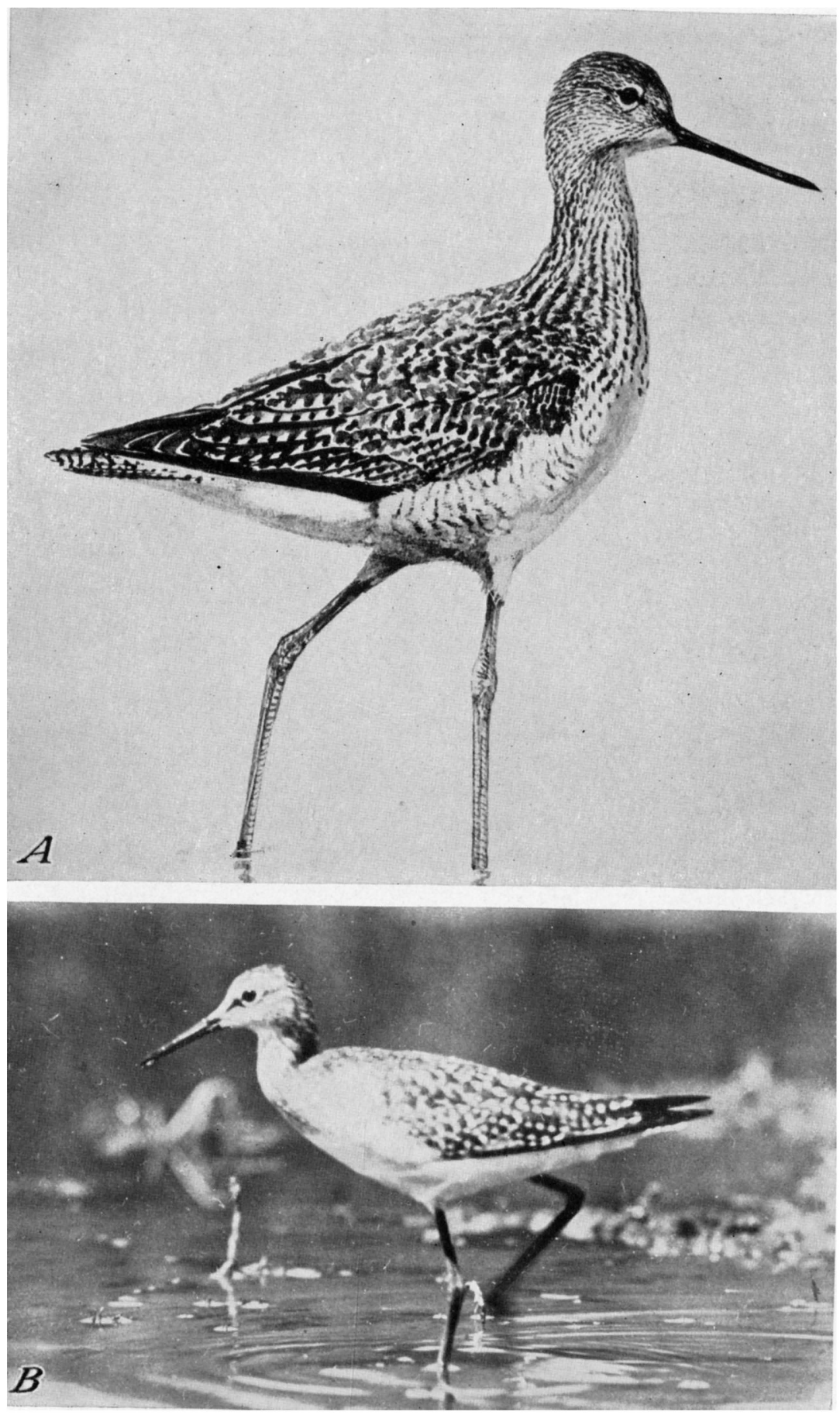

$A$, Greater yellowlegs; $B$, lesser yellowlegs.

B3753M; B1156M 


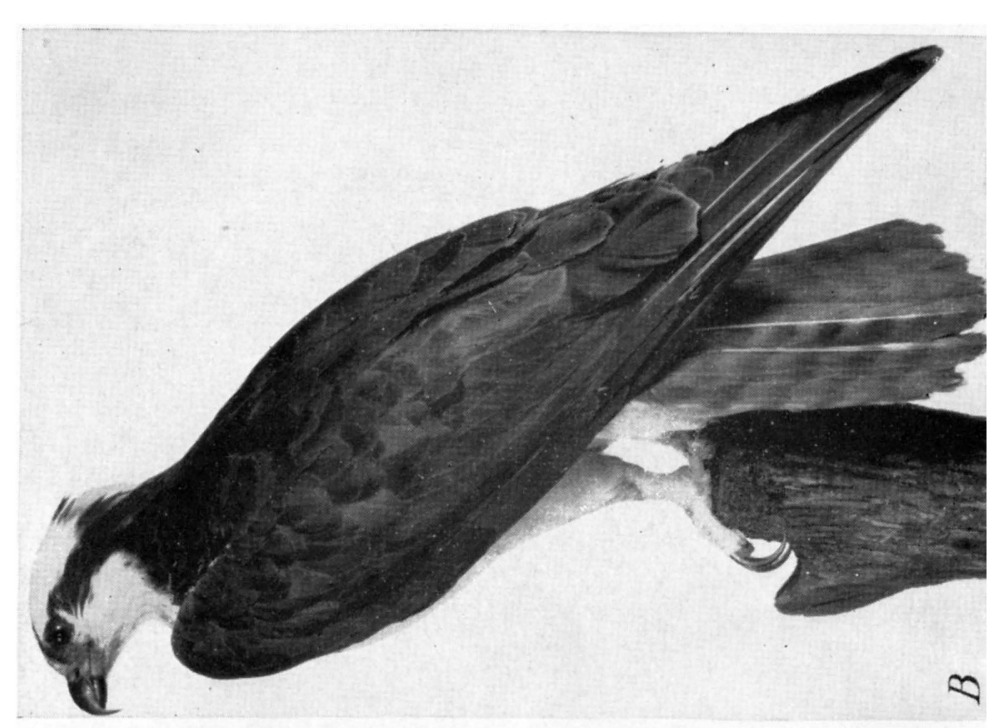

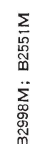

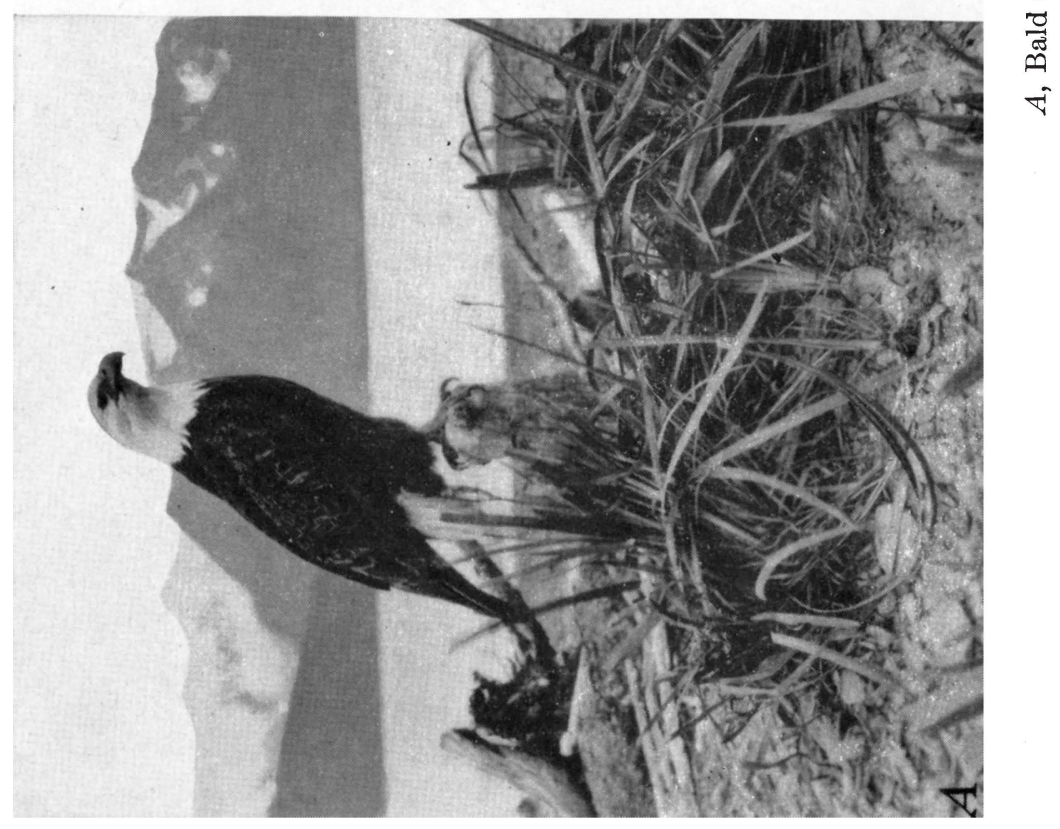


one on mud, about 5 to $63 / 4$ inches long, with greenish-yellow legs and a slightly down-curved bill, is likely to be the least sandpiper, or mud peep ( $P$. minutilla). It does not breed in the Atlantic Coast States but occurs in all of them in migration and winters from North Carolina southward. It frequents muddy beaches everywhere and is often seen in salt marshes, sometimes assembled in great flocks. From the large numbers and small size of the sandpipers associating in these flocks, the birds are locally called "bumblebee peeps."

The spotted sandpiper (Actitis macularia) frequents both wet grassy and muddy areas. Although chiefly a fresh-water associate, it is so universally distributed that individuals at times are likely to visit salt marshes. This bird, $61 / 2$ to 8 inches long, is grayish brown above and white below, marked with round dark spots that distinguish it from any other shorebird. It is constantly bobbing and is on that account widely named "teetertail." Whentaking flight, it cries peet-weet and with down curved wings alternately flaps and sails, usually not far before alighting.

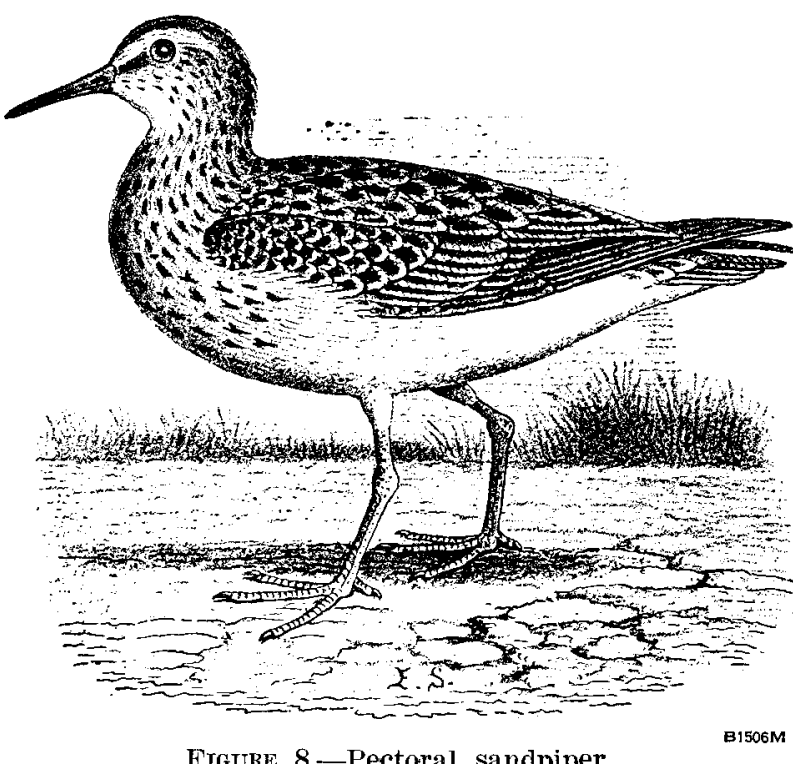

Frgure 8.--Pectoral sandpiper.

It was pointed out by the writer in 1911 (p. 9) ${ }^{4}$ that shorebirds deserve protection because of their beneficial feeding habits. Where local conditions permit, the birds are highly insectivorous, feeding on grasshoppers; caterpillars, including such pests as the armyworm, cottonworm, and cutworms; and beetles, including billbugs and wireworms. They eat also adults and larvae of horseflies and mosquitoes (hundreds of mosquito wigglers having been found in single stomachs), as well as water beetles and their larvae which prey upon small fishes; marine worms, which devour oysters; ticks, which carry cattle fever; and crawfishes, which are destructive to crops and embank-

${ }^{4}$ McAtee, Waldo Lee. Our vanishing shorebirds. U. S. Biol. Survey Circ. 79, 9 pp., illus. 1911 . 
ments. Shorebirds not only thoroughly deserve protection but must have it to exist. They lay but once a year, no more than three or four eggs, so that probably only one or two young are reared by a pair. Most of them, moreover, perform long migrations beset by hazards, many of them migrating along narrow routes in which their whole populations are concentrated and where they would rapidly be killed off if exposed to attack by the army of hunters today. With the exception of a few species, shorebirds have been protected at all seasons ever since the passage of the Migratory Bird Treaty Act in 1918 and despite some poaching have responded encouragingly to protection.

OSPREY

The osprey, or fish hawk (Pandion haliaetus) (pl. 6, B), breeds all along the coast and winters from the Middle Atlantic States southward. It is a rather large bird, 21 to 25 inches long, with a wingspread of 54 to 72 inches. It is dark above and pale below, with a good deal of white about the head. The tail and wings are chiefly barred, dusky and white. The long wings often appear angled in flight. The bulky nests are frequently placed on tall stubs but sometimes are built in a variety of other sites. The eggs, usually three, are from white to reddish brown, heavily spotted with deep brown. In feeding, the fish hawk hovers over the water and plunges in after its prey, which consists almost entirely of fishes, as a rule chiefly noncommercial varieties. Without regard to that fact, this bird has long been looked upon with favor by fishermen, a fortunate circumstance. As the osprey is specialized to get its food from the water and will not come to the ground even for prey it has accidentally dropped, there seems little likelihood of its attacking poultry, rabbits, or other landlubbers.

\section{BALD EAGLE}

The bald eagle (Haliaeetus leucocephatus) (pl. 6, A) lives almost throughout North America and breeds near if not in salt marshes, for it is chiefly a coastal bird. It is larger than the osprey, being 30 to 34 inches long, with a wingspread of 72 to 85 inches. The adults are dark brown, with the entire head, neck, and tail white. The young lack the white head and tail and are chiefly dark, though some appear blotched. Their size and similarity to the adults in action and habits, however, will identify them. The nest usually is larger and placed in a higher tree than that of the osprey. The eggs, normally two, are yellowish white. The long, broad wings are flapped rather slowly and are much used in soaring. Although an expert in flight and powerful enough to capture almost any of the forms of wildlife on the coast, the bald eagle is by preference a scavenger. Dead fishes and other animals picked up on beaches and 
mud flats are its most common food, although crippled wild fowl are soon found and dispatched and a certain proportion of ablebodied prey is taken. The eagle has long been reputed to harass the osprey until it drops its catch, which the eagle then recovers and devours; but according to the writer's experience, this must be an uncommon performance. The bald eagle does little harm to healthy wildlife and is a magnificent bird, a master of the air, and the embodiment of freedom. It should be preserved both for its own sake and because it is the national emblem. It is now protected by Federal law.

VULTURES

Vultures, or buzzards, as they are commonly called in this country (the European buzzard is a large hawk), have no particular connection with salt marshes, but they are great fliers that may frequently pass over them. These large birds are chiefly black, with the skin of the head and neck bare like that of a turkey, for which one of them, the turkey buzzard, or turkey vulture (Cathartes aura), is named. 'This species, with the head and neck red, is common north to New Jersey but only a straggler beyond; and the black vulture (Coragyps atratus), with those parts black, is common north to Maryland. Both species inhabit the Southern States, and as both feed chiefly on carrion, they are likely to be attracted by dead fishes along the shore. Vultures are seen in the air a great deal on windy days or on days when strong sunshine creates rising columns of air, the turkey vulture being especially adept at soaring.

CROWs

Crows need no description. 'Two of them, the upland crow and the fish crow, visit the Atlantic coast salt marshes, but they are not readily distinguished by the inexperienced. The upland crow (Corvus brachyrhynchos), of almost continental range, averages somewhat larger than the coastal fish crow, however, and appears of sturdier build, particularly as to the chest, head, and beak. It is more accustomed to long flights and as a rule goes directly on its way with steady, sweeping wingbeats. Its caw is hoarser and guttural. The fish crow ( $C$. ossifragus) has a more vacillating flight and a higher-pitched and nasal car. It resides along the coast and the estuaries of larger streams, where the upland crow usually is only a visitor, and occurs regularly from the southern coasts as far north as Connecticut but only as a straggler beyond that State.

Crows eat almost anything, and the upland species sometimes becomes injurious to crops. The fish crow has little contact with farms, but it shares with its inland relative a fondness for the eggs and young of other birds that from man's point of view sometimes seems 
too pronounced. In the salt marshes, undoubtedly a high percentage of the eggs eaten by crows are those of the clapper rail, or marsh hen, and it has never even been suggested that the numbers of that bird are thereby reduced. Under some conditions, as after the flooding of nests of clapper rails and other birds in salt marshes by ex-

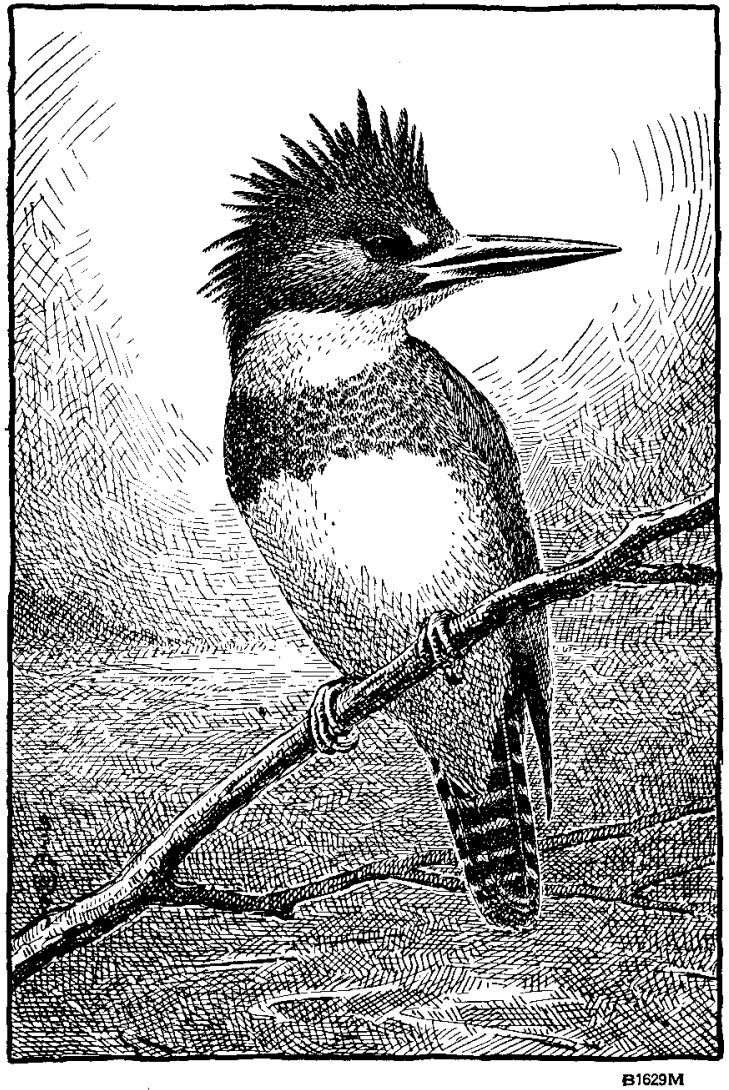

FIGURE 9.-Belted kingfisher. ceptionally high tides, eggs are washed out in windrows, and then their consumption by crows has no unfavorable significance. 'The writer has heard crows condemned on account of the number of eggshells found under their nesting trees, when it was perfectly evident that most of these were from drowned-out nests of the clapper rail. This is said in extenuation of the food habits of crows because of the prevalence of immoderate condemnation. The lesson is to observe carefully and to find out all possible about crow-egg relationships, or for that matter about any wildlife problem, before taking any action. Then there should be done what seems necessary, but no more.

\section{IKINGFISHER}

The belted kingfisher (Megaceryle atcyon) (fig. 9) frequents salt marshes where there are bare limbs, stakes, or other exposed perches. It breeds in holes in banks from southeastern Canada to South America and winters along the coast from Massachusetts southward. This slaty-blue bird, 11 to $143 / 4$ inches long, with a well-defined, erectile crest, has a ring around the neck and the under parts chiefly white. The bill is stout and longer than the head. The female is marked by a 
cinnamon band across the breast below the slaty-blue one possessed by both sexes. The bird frequently utters a loud, harsh rattle. It captures fishes by plunging for them, and its fishing in salt marshes probably does little harm. About hatcheries and rearing ponds, however, the bird must be controlled. This is usually done by shooting or trapping, but screening all fishponds of moderate size would be preferable. ${ }^{5}$

\section{GRACKLES}

The boat-tailed grackle (Cassidix mexicanus) (fig. 10), almost universally called jackdaw, is a bird of the coast from southern Delaware southward. The male is mostly black, with bluish an.d greenish reflections; the female, chiefly buffy brown, with wing $\mathrm{s}$ and tail darker. The male measures 15 to 17 inches, of which more than a third is tail; the female, 12 to 14 inches. The tail is troughshaped, a character particularly well displayed in flight.

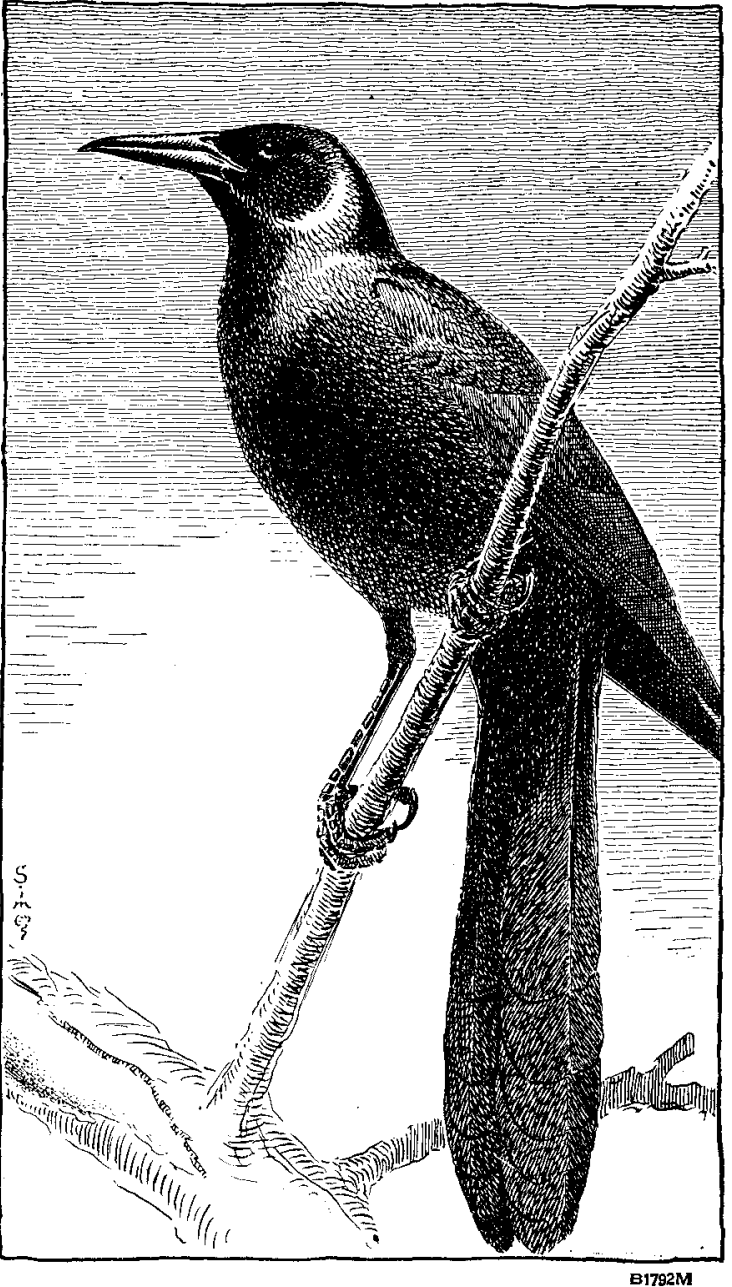

Figure 10.-Boat-tailed grackle.

These birds feed a great deal about salt marshes and are not afraid of the water, in which they wade and submerge their heads in search of shrimps, small crabs, and snails. They eat crawfishes and insects also and occasionally damage grainfields near the coast. Jackdaws are noisy, making a variety of harsh, guttural calls. The purple grackle (Quiscalus quiscula), an inland species, somewhat

\footnotetext{
${ }^{5}$ See footrote 3, p. 14 .
} 
smaller, with the sexes more nearly alike in dark and metallic coloration, may sometimes visit the marshes and be seen in company with the boattails.

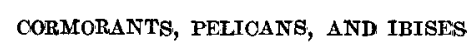

Several water birds that frequent the South Atlantic coast are briefly mentioned, as occasionally they may be seen in salt marshes.

The double-crested cormorant (Phalacrocorax auritus), also known as "shag," or "nigger goose," a glossy, greenish-black bird somewhat smaller than the Canada goose and rather heavy in flight, winters from Virginia (sometimes from New Jersey) southward, but a related race is resident all the year in Florida. The cormorants spend much time perched, for purposes of drying and preening, and when quiet suggest so many large black bottles. They are expert fishers and can catch almost anything they want. In some places they are destructive but on the whole consume more of the less valuable fishes than of game and commercial species.

Almost everyone has read about pelicans or has seen pictures of them, so that recognition of the birds in life is not difficult. Brown pelicans (Pelecanus occidentalis) winter on the Florida coast and summer as far north as South Carolina. They characteristically fly in files, alternately flapping and gliding. When fishing, they plungealmost, it would seem, awkwardly fall-into the water when a fish is spied near the surface. They subsist very largely on menhaden, thread herring, and other fishes not used for human food. Of the food fishes they probably take more mullets than any other kind.

The white ibis (Guara alba) breeds from South Carolina and win. ters from Florida south. It is usually seen in flocks. From 24 to 37 inches long, it is almost entirely white but has black wing tips and a long, down-curved, reddish bill. Because of the curved bill, it is often called curlew, preceded by such modifiers as white or Spanish. The wood ibis (Mycteria americana) may be seen both winter and summer from South Carolina southward. A much larger bird, 35 to 37 inches long, it also is mostly white but has dark flight feathers and tail. The head and upper neck are unfeathered and scaly. The ibises differ from the herons in that they fly with the neck as well as the legs stretched out.

WARRLERS AND SWALTOWS

In winter two small land birds, the myrtle warbler and the tree swallow, are likely to be common enough near or in southern salt marshes to attract attention. Both birds consume insects whenever available and feed chiefly on them during the warmer months, as do all their kin. Birds of their respective families are legally protected throughout the Union. 
The myrtle warbler (Dendroica coronata) winters regularly from New Jersey (casually from New England) south and sometimes swarms near the coast from the Carolinas southward. It is a little less than 6 inches long and is chiefly bluish gray above and white below, streaked with black; and the crown, the rump, and a spot on each side of the breast are yellow. This attractive little bird frequently utters a characteristic and rather loud tohip. It feeds to a considerable extent on the fruits of the bayberry or waxmyrtle, a habit alluded to in the standard vernacular name. This habit, an unusual one for warblers, a highly insectivorous group of birds, enables the species to winter farther north than any of its relatives.

A remark to the same purport is in order respecting the tree swallow (Iridoprocne bicolor), and the berry-eating habit seems even more remarkable in its case. This species is seen in winter regularly as far north as North Carolina and occasionally as New Jersey. It is glossy bluish green above and white below. Like others of its tribe it goes much in company and is expert in flight.

\section{OTHER WILDLIFE OF THE SALT MARSHES}

Birds are a more prominent element of the wildlife of marshes than are some other groups, no doubt because of the ease with which they come and go--they do not have to stay but are free to visit. Temporarily frequenting a salt marsh, however, is very different from living there permanently, which requires close adaptation. As we have seen, relatively few birds are fitted for such exclusive residence. The same is true among other kinds of wildlife; and the amphibians (toads, frogs, salamanders, and the like), one important group, are totally banned from the marshes because their tender skins will not endure salt.

\section{REPTILES}

Comparatively few reptiles penetrate the salt marshes, though of course a number may be found near the landward edge (this is true of the amphibians, too), where conditions may become radically. different in a short distance.

The alligator (Alligator mississippiensis), which all will recognize on sight, occasionally sojourns in salt water and at times, therefore, may be seen in the marshes. Its normal range is from North Carolina southward, but a few alligators, possibly escaped from captivity, have been found as far north as New Jersey. Alligators deposit their eggs in layers in mounds of muck and vegetation scraped together by the females. Owing to the heat produced by the rotting of the vegetation, the mounds serve as incubators. The animals usually have individual deep holes, or dens, under water. They feed on crabs, crawfishes, water insects, fishes, turtles, and sometimes 
larger creatures. There are old records of alligators 20 feet or more long, but now a 12-foot animal is a very large one and 15 feet is about the limit of verified size. Because alligators have been hunted for their hides, which are used extensively by the leather industry in making traveling bags and in ornamental leather work, their numbers have been greatly reduced.

The diamondback terrapin (Malaclemys centrata) (pl. $7, B$ ) is a natural denizen of salt marshes from New Jersey southward. Its not very fitting name is suggested by the concentric ridging of the plates of the carapace, or upper shell. This turtle is plainly colored, greenish to black. It is the favorite catch for turtle stew and has been so hinted for the market that it is rare in most localities. Some success has been attained in raising it in captivity.

The cottonmouth moccasin (Agkistrodon piscivorus) (pl. 7, A), a dangerously poisonous snake, is semiaquatic and a good swimmer. Apparently unafraid of salt water, it may be found along the coast from North Carolina south. It is of stocky build and may attain a length of 6 feet. Its general color is dark chestnut brown with some darker barring; the throat and some slight stripes about the head are yellowish white. The common name refers to the white lining of the mouth, which, it is said, the snake displays briefly before biting. The head is triangular and distinctly wider than the neck, a characteristic of most poisonous snakes of the United States and a useful mark for distinguishing this species from the large, dusky common water snake, which may look surprisingly like a dully colored cottonmouth moccasin. Cottonmouths are not aggressive, and when they bite a person it is usually because they have been stepped on. Emergency treatment involves placing a tourniquet between the wound and the heart, loosening it for a minute or two every 10 or 15 minutes; cutting open the wound to secure good drainage; and removing as much of the venom as possible by suction, which should be done with a stout rubber tube. Suction should not be by mouth, unless there is no other way, as the venom may be absorbed through abrasions in the lining of the mouth. ${ }^{6}$

FISHES

It is not in the province of this circular to treat of the fishes of salt marshes, but it should be mentioned that the waters of these marshes harbor large numbers of certain small fishes that are known to devour many mosquito larvae, or wigglers. Among them are several kinds of killifishes (Fundulus spp.), which occur in one form

\footnotetext{
6 For information on poisonous snakes and treatment of their bites see the following : Poisonous snakes of the United States. U. S. Bur. Biol. Survey Wildlife Res. and Mgt. Leaflet BS-70, $19 \mathrm{pp}$. 1936. [Processed.] Obtainable on request from the Fish and Wildlife Service, Washington, D. C.
} 
Wildlife Circ. 11, Fish and Wildlife Service

Plate 7
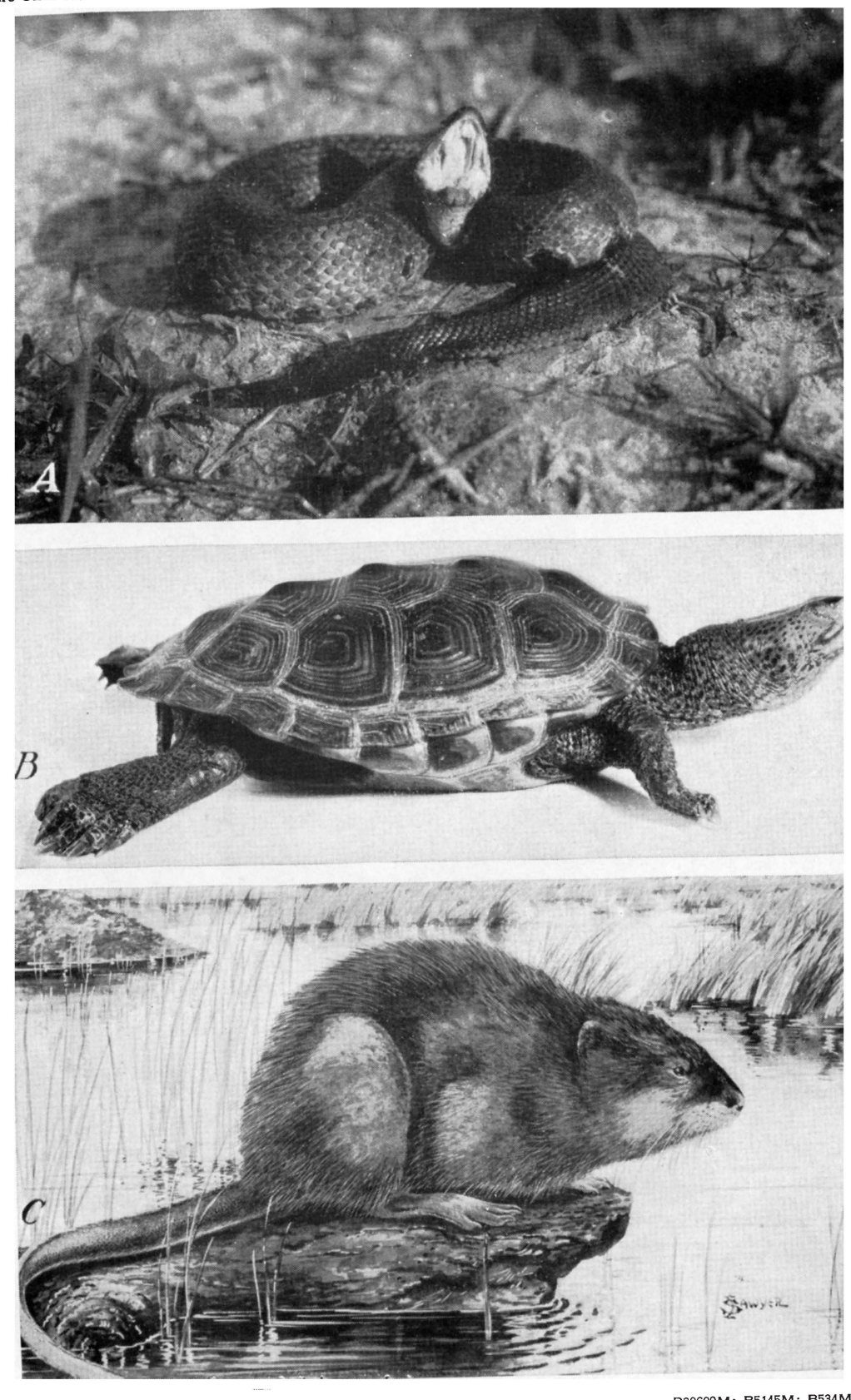

$A$, Cottonmouth moccasin; $B$, diamondback terrapin; $C$, muskrat. 
or another along the whole coast. These moderately stout fishes are mostly greenish, marked with dusky and pale cross bands, and are 2 to 6 inches in length when adult. Another is the pursy minnow (Cyprinodon variegatus), 2 to 4 inches long, which is found from Cape Cod southward. It also has faint cross bars but is higher bodied, more the shape of a sunfish. The male is bluish above, coppery below, and the female olivaceous. Yet another is the silversides (Menidia notata), which also occurs along the whole coast. This is a slender, translucent greenish fish, with a silvery streak along each side. Its maximum length is about 5 inches.

Proper ditching of salt marshes to control mosquitoes has as one of its objects that of making every bit of water area of the marsh accessible to the small larva- or wiggler-eating fishes. The reason for keeping all pools and ditches smooth- or clean-edged is to leave no cover where the mosquito larvae can escape the fishes.

\section{MAMMALS}

No species of fur animal or other mammal inhabits salt marshes exclusively. Meadow mice and muskrats may live in the marshes at all seasons but in colonies that are only outliers of a very extensive inland range.

Meadow mice, or field mice (Microtus pennsylvanicus), inhabit the marsh-hay zone and sometimes may be numerous. They are short-tailed, smoothly rounded little rodents, with not even the ears sticking out of the fur to any extent. Their average length is about 7 inches, about $51 / 2$ for the body and $1 \frac{1}{2}$ for the tail. These mice construct narrow, irregular, intersecting runways, some beneath the ground and some on the surface. The latter are easily seen on burned-over areas or in spring after the snow has melted away from the flattened vegetation. Meadow mice feed largely on vegetable materials and in salt marshes can do no harm. They are the most frequently captured prey of a number of kinds of hawks and owls.

In form, muskrats (Ondatra zibethica) (pl. 7, $C$ ) are not unlike meadow mice, but they are about 2 feet in length, of which nearly half is the bare, laterally compressed tail. They live in areas where bulrushes and cattails are abundant and eat all parts of these plants, which they use also as materials for the winter lodges. These are low, conical mounds, substantially built and standing high enough above the water line to provide ample space within for a dry, grass-lined living room, from which several passageways lead off in different directions under water. Muskrats are heavily trapped for fur, which ordinarily has a good valuation, considering the abundance of the animals. The revenue from the sale of skins 
on some controlled lands or muskrat farms has proved equal to or even greater than that from nearby agricultural lands.

Other occasional mammal visitors to the marshes include the otter (Lutra canadensis), the mink (Mustela vison), the raccoon (Procyon lotor), and the opossum (Didelphis virginiana), ali probably well enough known for there to be no question as to identity. 